Spring 5-2-2021

\title{
Wage Theft, Economic Conditions, and Market Power: The Case of $\mathrm{H}$-1B Workers
}

\author{
Peter Norlander \\ pnorlander@luc.edu \\ Jed DeVaro \\ Cal State East Bay, jed.devaro@csueastbay.edu
}

Follow this and additional works at: https://ecommons.luc.edu/business_facpubs

Part of the Human Resources Management Commons, Labor Economics Commons, and the Public

Policy Commons

\section{Recommended Citation}

Norlander, Peter and DeVaro, Jed. Wage Theft, Economic Conditions, and Market Power: The Case of H-1B Workers. Wage Theft, Economic Conditions, and Market Power: The Case of H-1B Workers, , : 2021. Retrieved from Loyola eCommons, School of Business: Faculty Publications and Other Works,

This Working Paper is brought to you for free and open access by the Faculty Publications and Other Works by Department at Loyola eCommons. It has been accepted for inclusion in School of Business: Faculty Publications and Other Works by an authorized administrator of Loyola eCommons. For more information, please contact ecommons@luc.edu.

\section{(c) $($ () $\ominus$}

This work is licensed under a Creative Commons Attribution-Noncommercial-No Derivative Works 3.0 License. 


\section{ECONSTOR}

Make Your Publications Visible.
A Service of

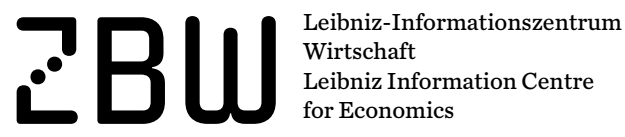

DeVaro, Jed; Norlander, Peter

\section{Working Paper \\ Wage Theft, Economic Conditions, and Market Power: The Case of H-1B Workers}

GLO Discussion Paper, No. 855

Provided in Cooperation with:

Global Labor Organization (GLO)

Suggested Citation: DeVaro, Jed; Norlander, Peter (2021) : Wage Theft, Economic Conditions, and Market Power: The Case of H-1B Workers, GLO Discussion Paper, No. 855, Global Labor Organization (GLO), Essen

This Version is available at:

http://hdl.handle.net/10419/234433

\section{Standard-Nutzungsbedingungen:}

Die Dokumente auf EconStor dürfen zu eigenen wissenschaftlichen Zwecken und zum Privatgebrauch gespeichert und kopiert werden.

Sie dürfen die Dokumente nicht für öffentliche oder kommerzielle Zwecke vervielfältigen, öffentlich ausstellen, öffentlich zugänglich machen, vertreiben oder anderweitig nutzen.

Sofern die Verfasser die Dokumente unter Open-Content-Lizenzen (insbesondere CC-Lizenzen) zur Verfügung gestellt haben sollten, gelten abweichend von diesen Nutzungsbedingungen die in der dort genannten Lizenz gewährten Nutzungsrechte.
Terms of use:

Documents in EconStor may be saved and copied for your personal and scholarly purposes.

You are not to copy documents for public or commercial purposes, to exhibit the documents publicly, to make them publicly available on the internet, or to distribute or otherwise use the documents in public.

If the documents have been made available under an Open Content Licence (especially Creative Commons Licences), you may exercise further usage rights as specified in the indicated licence. 


\title{
Wage Theft, Economic Conditions, and Market Power: The Case of H-1B Workers *
}

\author{
Jed DeVaro* \\ Peter Norlander ${ }^{* *}$
}

May 27, 2021

This study explores what determines employers' violations of the wage contracts of workers on H-1B temporary work visas, which occur when firms pay those workers below the promised prevailing or "market" wage. A theoretical framework is proposed that predicts more violations during economic downturns, fewer violations when firms have more labor-market power, and more violations by subcontractor firms. Empirical analysis is based on a firm-level matched dataset of wage and hour violations and the firms that sponsor H-1Bs. Higher labor market power, measured by the Herfindahl-Hirschman Index, is associated with fewer violations. Higher unemployment rates and subcontractor firms are associated with more violations. The effects of the unemployment rate and labor market power are amplified in subcontractor firms.

Keywords: wage theft, guest workers, H-1B workers, labor market competition, wage and hour laws, monopsony labor market

JEL Classification Codes: J31, J38, J42, J44

\footnotetext{
* The authors gratefully acknowledge helpful feedback from seminar participants at the $72^{\text {nd }}$ LERA meeting, the $91^{\text {st }}$ Southern Economic Association meeting, and the Wharton People and Organizations conference. Particularly helpful feedback was provided by David Weil concerning enforcement of wage theft violations by the Wage and Hour Division of the U.S. Department of Labor.

* The Wang Family Professor, Department of Management and Department of Economics, College of Business and Economics, California State University, East Bay; Hayward, CA 94542; Email: jed.devaro@csueastbay.edu

** Assistant Professor, Department of Management, Quinlan School of Business, Loyola University Chicago; Chicago, IL 60611; Email: pnorlander@luc.edu. GLO Fellow.
} 


\section{Introduction}

Employers sometimes pay workers less than what the law or a labor contract requires. Such violations, while more the exception than the norm, occur with sufficient frequency to be of concern to policymakers, the affected workers, and society in general. They have substantial social welfare implications, shifting surplus from workers to employers and undermining the wage floors imposed by policymakers. To the extent that such violations occur after the employment contract is agreed to they come as an unpleasant surprise to workers, which introduces uncertainty into wage contracts.

One defense against such exploitative employer behavior is labor mobility, the act of leaving the current or potential employer to pursue other opportunities, often with another employer who offers higher pay. Not all worker groups, however, have the same opportunities or enjoy the same degree of labor mobility. For example, foreign-born "guest workers", who arrive in a destination country on temporary work visas with the intention to return to their origin country after a period of employment, enjoy less labor mobility than domestic workers. ${ }^{1}$ These workers may suffer even worse treatment at the hands of employers if their mobility is further restricted for other reasons. In particular, guest workers are often caught in a secondary labor market of subcontractors, staffing agencies, and other labor market intermediaries. ${ }^{2}$

This study explores the determinants of wage violations against the "highly-skilled" guest workers (henceforth, H-1Bs) in the United States H-1B temporary visa program. Specifically, the roles of economic conditions, market power in the labor market, and subcontractor status are examined as determinants of wage violations.

\footnotetext{
${ }^{1}$ This is most evident when examining guest workers who subsequently obtain permanent residency: quit rates increase $4.6 \%$ the year after permanent residency is obtained (Hunt and Xie 2019). Some reasons why migrants have limited mobility include discrimination, linguistic and cultural barriers, limited information about job opportunities, and less developed social networks. This limited mobility gives employers greater market power over migrant than over domestic workers. See Amior and Manning (2020) for further discussion.

${ }^{2}$ In the U.S. H-1B visa program, labor market intermediaries are typically foreign-headquartered information technology services firms whose recruitment and subcontracting of guest workers is associated with within-firm increases in labor productivity. In contrast, "lead firms" are typically U.S.-based heavy users of the visa, including universities and firms in specific industries whose guest worker sponsorship is associated with increased patenting and investments in R\&D (Norlander and Varma 2019).
} 
Economic conditions can be expected to influence employers' tendency to commit wage violations. Recessions limit workers' mobility, given that labor demand is a derived demand and that demand for firms' products and services falls in recessions. Thus, wage violations should be less (more) common in a tight (weak) labor market with low (high) unemployment. The degree of market power in the labor market is a further consideration. Initial intuition might suggest a parallel argument to the preceding one for economic conditions: wage violations should be more common under monopsony than under perfect competition because labor mobility is greater under perfect competition than under monopsony, which makes workers more exploitable under monopsony. But that greater exploitability means that wages are already lower (even without wage violations) than under perfect competition, and with so much of the surplus already being extracted from workers, further wage cuts might be unprofitable. In the wake of an unexpected negative shock, a perfectly competitive firm needs to cut wages (thereby triggering a violation) just to survive, whereas a monopsonist need not. A monopsonist can potentially withstand the negative shock without cutting wages, albeit at a reduced profit level. That insight, which will be developed more fully in due course, is new.

The effects of economic conditions, labor market power, and the role of subcontractor status on firm-level wage violations have not been addressed in the literature. ${ }^{3}$ This study is the first with matched firm-level labor demand and violations data and is the first to model and test how these determinants effect wage theft. Three questions are of interest. First, what is the effect of economic conditions - specifically, shocks that reduce a worker's marginal revenue product on wage violations? Second, what is the effect of labor market power on wage violations? Third, why do subcontractor firms systematically commit more violations than other firms?

Addressing these questions requires clarifying how policymakers set wage floors and where those floors lie relative to the equilibrium wages that would prevail in the absence of

\footnotetext{
${ }^{3}$ Fine, Galvin, Round and Shepherd (2020) report that state-level increases in the unemployment rate during the great recession were associated with increased wage and hour violations. Marinescu, Qiu, and Sojourner (2021) find mixed evidence regarding the relationship between wage and hour violations and concentration: a negative association in OLS estimates but a positive association in an instrumental variable analysis. Different samples and contexts could account for these results. Although the role of subcontractor status as a determinant of wage violations has not been addressed in the literature, there is evidence more generally that business organization affects wage violations. For example, franchisees are more likely to commit violations than brand-owned chains (Ji and Weil 2015).
} 
institutional constraints on pay. Given that H-1Bs are highly skilled, the relevant wage floors typically lie considerably above the floors set by federal and state minimum wage laws. For H$1 \mathrm{Bs}$, the relevant floor - which applies for a duration of multiple years - is the prevailing or "market" wage within their occupation and geographic region. ${ }^{4}$ It is promised ex ante by the employer, and the ex post breach of that "attestation" (or contract) is a violation of wage and hour law. From a theoretical standpoint, this prevailing wage can be thought of as coinciding with the aforementioned equilibrium wage. Theory predicts that this equilibrium wage (and, therefore, the coinciding prevailing wage) varies by labor market structure, being lower under monopsony than under perfect competition. More precisely, under monopsony, the sole employer ${ }^{5}$ sets the wage equal to the worker's reservation utility, whereas under perfect competition the wage is bid up to a level that exceeds the worker's reservation utility.

But if equilibrium wages and wage floors coincide, why would wage violations ever be observed? Cutting the wage below its equilibrium level would be unprofitable (even abstracting from administrative fines that are imposed if the employer is caught in a violation) due to costly turnover; under monopsony, the worker would quit to take the reservation option, under perfect competition the worker would quit to take a job with another employer, and in either case the worker's original employer would earn zero profit. One explanation for wage violations is that an unanticipated, negative shock (a recession) occurs that is common to all firms in the market. Whereas the prevailing wage stays fixed for multiple years, the equilibrium wage drops in the wake of the negative shock. With the prevailing wage exceeding the new equilibrium wage, a monopsonist can increase profit via a wage violation, as long as the expected administrative fine imposed on the employer (if caught) is sufficiently low. Firms faced with a perfectly competitive

\footnotetext{
${ }^{4}$ As observed in Manning (2020): "Prevailing wage provisions seek to ensure that migrants on work visas are paid the going rate and do not undercut existing workers, but enforcement may be imperfect."

${ }^{5}$ Although there is only one employer in a pure monopsony, employers have a degree of monopsony power even in labor markets with many employers, and that market power is used to lower wages (Manning 2003; Webber 2015; Sokolova and Sørensen 2021). Labor market frictions and heterogeneous worker preferences can give rise to imperfect competition.
} 
labor market have an even stronger imperative to engage in wage violations because post-shock profit is negative, so wage violations are necessary just to keep the firm operational. ${ }^{6}$

This study presents a theoretical framework that formalizes the preceding ideas. The main insight is that an increase in market power can make wage violations less likely to occur. When the prevailing wage lies above the equilibrium wage, either because of the policymaker's initial mandate or because of an unanticipated negative shock that breaks the equality between those two wage levels, a perfectly competitive firm must violate the prevailing wage just to stay in business with non-negative profit, whereas the monopsonist will do so only if the expected penalty from getting caught is sufficiently low. This insight is important because one's initial intuition might suggest exactly the opposite result - that wage violations should be more likely to occur under monopsony. ${ }^{7}$ The theoretical framework can also explain the greater prevalence of wage violations at subcontractor firms. Recall that under the monopsony market structure the employer sets wage levels equal to the worker's reservation utility. Reservation wages are persistently lower for H-1Bs in subcontractor firms than in lead firms, as explained in section 3.2.3. The model shows that subcontractors that employ workers with systematically lower reservation wages have greater incentives to commit wage theft in the presence of administrative fines. $^{8}$

Consistent with the theoretical framework, this study presents a novel empirical finding that greater market power is associated with more employer compliance with prevailing wage requirements. It is the first to examine the effect of labor-market concentration - or, more generally, any aspect of labor-market competitiveness - on violations of U.S. wage and hour law

\footnotetext{
${ }^{6}$ This suggests an alternative rationale for wage violations that does not involve an unexpected, negative shock. The policymaker might initially set the prevailing wage at a level that exceeds (rather than equals) the equilibrium wage, so that the initial situation matches the post-shock scenario just described.

${ }^{7}$ After all, when there is only a single employer, workers' labor mobility is limited in that they cannot go work for a competing employer. In contrast, under perfect competition there is substantial mobility: an employer cannot cut the worker's pay without losing them to a competing employer. Thus, it might seem that workers should be easier to "exploit" via wage violations under monopsony. This interpretation is provided in Marinescu, Qiu, and Sojourner (2021). Complicating this interpretation, frictions in the labor market, and not concentration alone, also pose barriers to mobility, and evidence suggests firms do not use all of their monopsony power (Gibbons et al. 2019).

${ }^{8}$ In practice, an ongoing challenge for policymakers is the high prevalence of violations by subcontractors at "fissured" workplaces, where subcontractors employ many of the workers who work for a lead firm (Weil 2018).
} 
against guest workers. The second main result concerns the effect of economic conditions on wage violations. Specifically, the unemployment rate (an indicator of a widespread negative shock from a recession) is positively associated with wage violations. Third, subcontractors commit more wage and hour violations, and the first two results are stronger in subcontractor firms than in lead firms.

The analysis uses unusually comprehensive data that include: 1) firm-level measures of wage and hour violations; 2) a census of firm-level labor demand to create measures of the extent of labor market concentration; and 3) an indicator of whether the firm is a subcontractor. Even though subcontractors represent only $7 \%$ of firms in the sample, they sponsor $27 \%$ of the H-1Bs. The result that the unemployment rate is positively related to wage violations is amplified for subcontractors, and the result that labor-market concentration is negatively related to wage violations is driven entirely by subcontractors. Thus, a relatively small fraction of firms account for the wage violations against $\mathrm{H}-1 \mathrm{Bs}$ in these data, and they are comprised heavily of subcontractors.

This work relates to Marinescu, Qiu, and Sojourner (2021) and to a large literature on monopsony that is reviewed in Manning (2020). The measure of market power that serves as an independent variable is labor market concentration, specifically the Herfindahl-Hirschman Index (HHI), as in Azar et al.(2020). Related prior research has studied employer concentration and institutional barriers to job mobility as potential causes of wage exploitation of guest workers (Naidu, Nyarko, and Wang 2016; Depew et al. 2017; Gibbons et al. 2019; Hunt and Xie 2019). Of particular relevance is Gibbons et al. (2019), which explores why, in the context of guest worker programs, firms with market power do not use it to pay workers less.

There is also a related literature on wage theft, which frequently involves violations of wage and hour laws. ${ }^{9}$ Much of that literature focuses on enforcement of laws to protect workers from wage theft (Ashenfelter and Smith 1979; Weil 2005; Bernhardt et al. 2009; Fine and

\footnotetext{
${ }^{9}$ Wage theft, which is the most common cause of federal legal action by guest workers against their employers (Gibbons et al. 2019), means failing to pay the worker the amount promised. The literature often treats the term as synonymous with non-compliance with wage and hour law, but the concepts require distinction. Wage theft comes as a surprise to workers, whereas non-compliance might not (for example, if a worker voluntarily enters a contract with full knowledge of the noncompliant pay, then no promise or contract is broken). Wage theft can also occur even in the absence of any wage and hour laws. Chapter 2 of DeVaro (2020) discusses wage theft as contract failure.
} 
Gordon 2010; Bobo 2011; Weil 2012; Bernhardt, Spiller, and Theodore 2013; DeVaro 2014;

Gleeson 2016; Borjas and Cassidy 2019). A number of studies documented the prevalence (and under-reporting) of wage theft, examined franchising and other "fissured" employment structures, and highlighted a need for industry-targeted, proactive and strategic investigation, as opposed to a passive approach based on responding to complaints (Weil 2005, 2009, 2012; Weil and Pyles 2005; Bernhardt et al. 2008; Bobo 2011; Bernhardt, Spiller, and Theodore 2013; Ji and Weil 2015).

\section{Institutional Background: The H-1B Guest Worker Program}

A stated goal of the H-1B program is to address the global competitiveness challenge of American companies facing "shortages in particular fields" (Hatch 2000). ${ }^{10}$ The notion of a labor shortage suggests a highly competitive labor market in which jobseekers enjoy many options. Typically, a highly competitive labor market protects workers from maltreatment by employers (low wages, or wage theft), because workers have many options for alternative employers and can always quit to work elsewhere. ${ }^{11}$ Contrary to the program's goal, evidence raises doubts about whether employers are seeking guest workers exclusively in the most competitive labor markets. $^{12}$

The H-1B program imposes regulations on both employer and worker behavior, some of which promote and some of which limit labor mobility and the degree of labor market

\footnotetext{
${ }^{10}$ A large literature documents the contributions of $\mathrm{H}-1 \mathrm{Bs}$ to national competitiveness through innovation and productivity. The 2015 special issue on "US High-Skilled Immigration in the Global Economy" in the Journal of Labor Economics features several articles concerning H-1Bs (See, for example, Peri, Shih, and Sparber 2015; Bound et al. 2015; Hunt 2015; Kerr, Kerr, and Lincoln 2015) and is a gateway into the literature.

${ }^{11}$ The notion that H-1B labor markets are highly competitive and characterized by labor shortages is not universally accepted. Cappelli (2015) argued that there is "little merit" to the claims of labor shortages that are used to justify guest worker programs. Citing a lack of compelling evidence of skill shortages requiring H-1B workers, Abraham (2015) recommended: a) removing barriers that make it difficult for guest workers to quit, and b) requiring employers to make efforts to recruit U.S. workers prior to hiring guest workers.

12 The evidence suggests that employers have sought foreign-born workers in regions where unemployment is higher under the permanent labor certification program ("PERM") for green card applicants (Rissing and Castilla 2016). Firm-level evidence also suggests that H-1Bs may crowd out domestic workers (Doran, Gelber, and Isen 2014) and that firms which are more dependent upon $\mathrm{H}-1 \mathrm{Bs}$ are more likely to pursue cost-reduction (or labor arbitrage) strategies (Norlander and Varma 2019).
} 
competition. Only workers in occupations requiring "highly specialized knowledge," such as science, technology, engineering, and mathematics (STEM) occupations, are eligible for visas. Such workers are presumably in high demand, suggesting high labor mobility. At the same time, the H-1B rules limit workers' mobility, because the visa (and legal status within the U.S.) is lost when an employment separation occurs, unless the worker quickly finds a new job with another employer who sponsors H-1Bs. With an initial three-year visa that can be renewed once, many guest workers hope to find an employer that will sponsor them for permanent resident status. In a tight labor market with low unemployment rates, H-1Bs may be able to find higher-paying jobs, but in a weak labor market, they are less likely to quit and are more likely to be sent back to their home countries (Depew, Norlander, and Sorensen 2017).

Employers are required to clear certain "labor market tests" that are intended to ensure that guest workers are not paid less than native workers in the relevant labor market (Griffith 2009). For H-1Bs, employers must attest in a "Labor Condition Application" (LCA) that they will: 1) pay the higher of the prevailing wage in the local labor market within a region and occupation, ${ }^{13}$ and the actual wage of workers in the same occupation, 2) provide the same benefits and working conditions to guest workers as native workers, and 3) not use guest workers to replace native workers who have been laid off or are involved in a labor dispute with their employer. Further, an employer with more than $15 \%$ of their U.S. workforce comprised of H-1Bs is required to pay the $\mathrm{H}-1 \mathrm{~B}$ worker the higher of $\$ 60,000$ per year in wages or the previously described required wage, or clear additional labor market tests related to non-displacement, recruitment, and hiring of U.S. workers. Failure to pay at least the amount on the LCA is a wage violation. ${ }^{14}$ An employer's filing of an LCA does not imply that a migrant worker is ultimately

\footnotetext{
${ }^{13}$ Employers are responsible for choosing the appropriate prevailing wage for each workplace by selecting the relevant occupation and skill level in a wage survey, most often the Bureau of Labor Statistics (BLS) Occupational Employment Survey. The wage floors are considerably higher than those in other labor markets, either domestically or within the Organisation for Economic Co-operation and Development (OECD) member countries (Dube 2014).

${ }^{14}$ Enforcement for wage violations against H-1Bs is handled by the Wage and Hour Division (WHD) of the U.S. Department of Labor. The WHD's authority and responsibility derive from the Immigration and Nationality Act (INA), the Fair Labor Standards Act (FLSA), the Migrant and Seasonal Agricultural Worker Protection Act (MSPA), and from regulations defined by the U.S. Department of Labor. For H-1Bs, the WHD's enforcement role is passive in that it can only respond to complaints and cannot proactively target specific firms or industries for investigation. The WHD is required to investigate each $\mathrm{H}-1 \mathrm{~B}$ complaint, issue a formal determination, and (if the complaint is corroborated) require the payment of back wages. See the Appendix for further details.
} 
hired at the stipulated wage (or at all). It is merely a documented statement of an employer's intent to recruit a guest worker in a certain location and at the wage required for that type of worker in that geographic region. ${ }^{15}$

\section{Theoretical Framework}

This section provides a simple theoretical framework for understanding the study's main empirical results. The goal is to illustrate an employer's propensity to violate prevailing wage laws under the two polar extreme labor market structures (monopsony and perfect competition) in the wake of negative shocks, and how this differs between lead firms and subcontractors. Consider a two-period setup with no discounting. There is a single potential worker with perperiod reservation utility, $U$, where $U>0$. The analysis is developed separately under the two market structures. A single employer is assumed in the case of monopsony and $N$ identical employers (engaged in Bertrand-style wage competition) in the case of perfect competition. All employers are assumed to maximize expected profit.

At the start of period 1, employers attempt to hire the worker by making a per-period wage offer of $W_{O}$, where $W_{O}>0$, anticipating that in each period of employment the worker will generate revenue of $R$, where $R>U$. Wages are to be paid to the worker at the end of each period of employment, as payment for the work that was done during that period. In the middle of period 1, an unexpected negative shock (a recession) hits and lasts through the end of period 2. The event is unforeseen by both the worker and the employers and affects all employers. It reduces per-period revenue from $R$ to $(1-d) R$, where $0<d<d^{*}$, with $d^{*}$ defined later in the analysis. The employer must then decide whether to pay the worker as promised, cut the worker's wage, or fire the worker and shut down production. Let $W$ denote the wage that is actually paid to the worker at the end of each period, where $W \leq W_{O}$.

\footnotetext{
15 The effective minimum wage imposed on H-1Bs prevents employers from (legally) paying them considerably less than native workers. Absent the regulation, employers may be tempted to do so given H-1Bs' restricted labor mobility. H-1Bs' market wage, therefore, would be expected to lie below that of equally able native workers, absent the regulation. The wage floor also diminishes employers' appetite for hiring guest workers instead of native workers, because (when enforced) it is impossible to legally hire guest workers "on the cheap."
} 
The preceding setup is analyzed in section 3.1 (first for monopsony and then for perfect competition) for the benchmark case in which there are no institutional constraints on pay. That analysis is then repeated in section 3.2 for the more interesting case in which there are institutional constraints on pay, specifically prevailing wage laws and penalties that employers incur if they are caught violating those laws. The benchmark analysis in section 3.1 highlights some basic intuition about employer behavior that remains true in the regulated environment of interest and that drives outcomes in that environment.

That basic intuition is simple but may appear counterintuitive at first glance. The question at hand is whether monopsonists or perfectly competitive firms are more likely to engage in violations in the event of a negative shock. Common intuition suggests that a monopsonist, as the sole employer of labor, is in the best position to "exploit" the worker by cutting wages, whereas competitive employers are constrained in their ability to lower wages because of the worker's threat to quit and work for a competing employer. But it is precisely the monopsonist's "exploitation" of the worker - paying the worker low wages - that prevents the monopsonist from engaging in wage theft in the event of an unexpected decrease in the worker's marginal revenue product. If the worker's pay is already so low that the worker is nearly indifferent between working and pursuing the reservation option, then any further cuts will induce the worker to quit. In contrast, in a competitive environment the worker's wage is bid up to a level higher than the reservation utility. This creates a buffer that allows the employer to cut wages, if necessary, without inducing the worker to quit to take the reservation option, as long as the negative shock is of limited magnitude and common to other employers in the labor market.

\subsection{Benchmark Case: No Institutional Constraints on Pay}

In the benchmark case, assume that $d^{*}=1-\frac{U}{R}$, which ensures that $d$ is small enough so that the post-shock surplus (whether accruing to the monopsonist as profit or to the worker in the case of perfect competition) remains positive.

\subsubsection{Monopsony}


As the sole buyer of labor, the monopsonist will offer a wage of $W_{O}=U$, which leaves the worker with zero surplus. The monopsonist anticipates reaping the entire surplus of $R-U$ as profit in each period. In fact what happens is that this per-period surplus is unexpectedly reduced to $(1-d) R-U$, which is still positive because of the assumed upper bound on $d$. In the wake of the unexpected negative shock, the monopsonist does not fire the worker (or cut their wage) because doing so would yield a period-2 profit of zero.

\subsubsection{Competitive Labor Market}

Bertrand wage competition implies that the worker is hired by one of the $N$ firms at a perperiod wage of $W_{O}=R$, which leaves all firms with per-period profit of zero and the worker with the entire anticipated per-period surplus of $R-U$, which accrued to the monopsonist as anticipated profit in section 3.1.1. In the wake of the unexpected negative shock, the worker's employer would suffer a per-period loss of $-d R$ by honoring the wage contract, which would require the firm to shut down. To avoid this loss, the employer decreases the wage from $W_{O}$ to $W=(1-d) R$, ensuring a per-period profit of zero for all firms. The worker's per-period surplus shrinks from $R-U$ to $(1-d) R-U$, which is positive, so the worker does not quit.

\subsection{Prevailing Wage Regulations}

The benchmark case shows that an unexpected negative shock induces a wage cut when the labor market is competitive but not when it is monopsonistic. This greater impulse to cut wages in the competitive case leads to a greater incidence of wage violations in an environment with prevailing wage regulations, as is now shown. Suppose that employers are legally obligated to pay (at least) the prevailing wage. Employers who fail to do so are caught with probability $p$ at the end of period 2 and must pay "back wages" for both periods, plus a fine in the amount of $k$, where $k>0$ and $p \in(0,1]$.

The prevailing wages correspond to the "market wages" that applied before the unexpected negative shock, and they differ between the two market structures. Call these prevailing wage levels $W^{m}$ for monopsony and $W^{c}$ for perfect competition. Henceforth, assume 
that $d^{*}=1-\frac{W^{m}}{R}$, which ensures that $d$ is small enough so that the post-shock monopsony profit remains positive.

Employers choose two wage levels in the model: an offered wage, $W_{O}$, that the worker is promised when hired, and a wage that is actually paid, $W$. Given that $W_{O} \geq W$, three possible scenarios arise concerning compliance with prevailing wage law: 1) both $W_{O}$ and $W$ are in violation, 2) $W_{O}$ is compliant but $W$ is in violation, 3) both $W_{O}$ and $W$ are compliant.

\subsubsection{Monopsony}

The prevailing wage, $W^{m}$, that the government imposes in monopsony markets lies in the range $U \leq W^{m} \leq R \cdot{ }^{16}$ Only two possible wage offers make sense for the monopsonist ( $W_{O}=W^{m}$ or $W_{O}=U$ ). An offer of $W_{O}=W^{m}$ is legal and avoids the risk of paying a fine, but it also sacrifices some profit that is converted to worker surplus. At a wage offer of $W_{O}=W^{m}$ the monopsonist anticipates receiving per-period profit of $R-W^{m}$, and the worker anticipates getting $W^{m}-U$, where the sum of these two parts equals the total anticipated surplus of $R-U$ from the benchmark case. ${ }^{17}$ Which of the two wage offers $\left(U\right.$ or $\left.W^{m}\right)$ the monopsonist makes hinges on how the benefits of wage theft (in the form of increased profit) compare to the expected cost of the fine. More precisely, the monopsonist offers $W_{O}=U$ when the following condition holds: $2(R-U)(1-p)+2\left(R-W^{m}\right) p-p k>2\left(R-W^{m}\right)$, which simplifies to $k<k^{*}$, where $k^{*}=\frac{2\left(W^{m}-U\right)(1-p)}{p}$. Thus, if the fine is sufficiently low, the monopsonist violates the prevailing wage law by offering a wage of $W_{O}=U$. If the preceding condition fails, the monopsonist remains in compliance with a wage offer of $W_{O}=W^{m}$.

Panel A of Figure 1 illustrates the monopsonist's wage-setting choices visually, assuming $R=10, U=5$, and $W^{m}=8$. The solid black curve graphs $k^{*}$ as a function of $p$. For values of $(p, k)$ that lie along that curve, the monopsonist is indifferent between compliance and non-compliance. For values of $(p, k)$ that lie above (below) that curve, the monopsonist chooses compliance (non-

\footnotetext{
${ }^{16}$ A monopsonist would never find it desirable to offer a wage below $U$, which would cause the worker to quit.

${ }^{17}$ Wage offers lying between $U$ and $W^{m}$ are not sensible, as they subject the monopsonist to the same expected penalty costs while ceding more of the surplus to the worker. If the monopsonist is going to risk getting caught and penalized, it might as well reduce the wage all the way down to $U$ as in the benchmark case.
} 
compliance). In the compliance region and along the $k^{*}$ curve that bounds it, profit is 4 for all values of $(p, k)$, because those parameters are relevant only in the non-compliance regime. In the non-compliance region, expected profit is a function of both $p$ and $k$ and is decreasing in both parameters, with the highest expected profit occurring in the neighborhood of the origin. As $p \rightarrow$ 0 and $k \rightarrow 0$, expected profit approaches 10 from below.

When the negative shock hits, regardless of whether the initial wage offer was $W_{O}=U$ or $W_{O}=W^{m}$, the monopsonist would not fire the worker, because doing so would reduce profit to zero. Similarly, the monopsonist would not cut the wage, because cutting the wage below $U$ when $W_{O}=U$ would cause the worker to quit (yielding zero profit) whereas cutting the wage below $W^{m}$ when $W_{O}=W^{m}$ would lead to a profit reduction. The profit reduction in the latter case would correspond to a wage cut from $W_{O}$ to $U$, because a larger wage cut would induce a quit (and therefore zero profit) whereas a smaller cut would be unprofitable for the reason given in the preceding footnote. If the offered wage is $W_{O}=W^{m}$, the reason the monopsonist does not find it optimal to cut the wage to $W=U$ after the shock hits is the same reason the monopsonist does not find it optimal to offer a wage of $W_{O}=U$ from the start $\left(k \geq k^{*}\right)$. Thus, in the wake of the negative shock, the monopsonist continues to employ the worker and to pay the initially promised wage, while suffering a drop in per-period profit from $R-W_{O}$ to $(1-d) R-W_{O}$.

The bottom line is that the monopsonist violates the prevailing wage law if $k<k^{*}$ and complies with it otherwise. Inspection of the critical threshold $k^{*}=\frac{2\left(W^{m}-U\right)(1-p)}{p}$ provides further intuition. When the prevailing wage, $W^{m}$, increases, compliance becomes costlier to the monopsonist, so $k^{*}$ increases, which expands the range of values of the fine, $k$, for which noncompliance is desirable. Similarly, when the worker's reservation utility, $U$, decreases, the monopsonist finds it even more tempting to "exploit" the worker via non-compliance, because considerable profit can be made by pushing the wage down as low as $U$. Thus, $k^{*}$ increases, which expands the range of values of the fine, $k$, for which non-compliance is desirable. If $p=1$, the monopsonist is certain to get caught in the event of a violation. Even if the fine is negligible in that case, it is still unprofitable to engage in wage theft because of the requirement to pay "back wages" in both periods, meaning that the monopsonist is guaranteed to pay a fine with nothing to show for it. In this case, $k^{*}=0$, so there are no values of $k$ for which wage theft 
occurs. If $p \rightarrow 0$, it is nearly impossible for the monopsonist to get caught in a violation, which makes wage theft appealing given that it shifts surplus from the worker to the monopsonist. In that case, $k^{*} \rightarrow \infty$, so that any value of $k$ is consistent with wage theft being profitable.

\subsubsection{Competitive Labor Market}

Assume that the government sets the prevailing wage in competitive markets, $W^{c}$, to $R$, which is the market value of the (pre-shock) competitive wage ${ }^{18}$ Bertrand wage competition implies that the worker is hired at a wage of $W_{O}=W^{c}=R$. Now the worker gets the entire surplus of $R-U$, because all employers make zero profit. When the negative shock hits, the employers' per-period profit from hiring the worker drops to $-d R$, which is a loss. The shock is assumed to affect all employers symmetrically. ${ }^{19}$ For any $d>0$, the employer must either fire the worker and shut down or cut the worker's wage to $W=W^{*}$, where $U \leq W^{*} \leq(1-d) R<R$, and profit is zero. ${ }^{20}$ That wage level is defined as follows:

$W^{*}=(1-d) R-\frac{p(k+2 d R)}{2(1-p)}$.

This expression reveals that $W^{*}$ lies below $R$ for two reasons. The first is the productivity drop due to the shock $\left(W^{*} \leq(1-d) R\right.$, the first term on the right-hand side of $W^{*}$, which coincides with the value of $W$ in the benchmark case of section 3.1.2) and the second is the possibility of getting caught and fined for violating the prevailing wage law (the second term on the right-hand side of $W^{*}$, which vanishes when $p \rightarrow 0$ and reduces to $\frac{d p R}{1-p}$ as $k \rightarrow 0$ ). Also note that $W^{*}$ decreases when either or both of $p$ and $k$ increase, because those two parameters determine the expected cost of getting caught. The bottom line is that wage theft or firm exit from the labor

\footnotetext{
${ }^{18}$ Values of $W^{c}$ above $R$ would never be respected due to negative profit. Values of $W^{c}$ below $R$ would not be relevant in the (pre-shock) equilibrium, because Bertrand competition ensures that no employer will offer a wage below $W_{O}=R$. But such values may become relevant, post-shock, if wage cuts are deep enough so that $W<W^{c}$.

${ }^{19}$ Strictly speaking, all that is required is that the negative shock affect all but one of the employers in the labor market symmetrically. If one employer remains unaffected, that firm will hire the worker and make positive profit, but the offered wage will be the same as that offered by all of the other (affected) employers who make zero profit.

${ }^{20}$ A deeper cut would imply positive profit, which would be bid away in Bertrand competition.
} 
market always occurs in the competitive case, ${ }^{21}$ whereas in the monopsonistic case it happens only when the administrative fine, $k$, is sufficiently low.

\subsubsection{Competition, Dual Labor Markets, and Subcontractors}

The model can also provide insight into the operation of the labor market for H-1Bs in subcontractor firms, ${ }^{22}$ as opposed to the "lead firms" that directly hire H-1Bs. In the H-1B program, many lead firms and universities recruit the "best and brightest," and these workers go on to patent and start firms at higher rates than native workers (Kerr and Lincoln 2010). In contrast, as critics of the H-1B program have observed in Congressional testimony and elsewhere, subcontractor H-1Bs are likely to be paid less than lead firm H-1Bs, have less stable employment in the U.S., are more likely to view a non-U.S. country as their permanent home, have fewer advanced degrees, fewer degrees from U.S. universities, and are less likely to be sponsored by their subcontractor employers to obtain green cards or become U.S. citizens (see Hira [2016, 2017], for discussion). Subcontractor H-1Bs face barriers to finding work at lead firms in the U.S., and subcontractor firms therefore systematically hire workers with lower reservation wages, a consequence of these H-1B workers' limited mobility.

Given that subcontractor and lead firm H-1Bs arguably work in distinct labor markets, the theory of dual labor markets offers a conceptual framework for understanding their differences. Dual labor market theory distinguishes between primary and secondary labor markets: workers in the primary market tend to have higher pay, more stable employment, higher skills, face less discrimination, and do not work for subcontractors or temporary employers (Doeringer and Piore 1971). ${ }^{23}$ Workers in the secondary labor market face difficulty accessing the primary labor market and have lower reservation wages than primary workers because

\footnotetext{
${ }^{21}$ This conclusion weakens somewhat if the prevailing wage is set to some value below $R\left(W^{c}<R\right)$. Then it is no longer the case that wage theft always occurs under perfect competition. To see why, suppose that $d$ is small so that only a small revenue loss is induced by the shock. Then a very small cut in the wage (to a value below the competitive wage of $R$ but still above the prevailing wage of $W^{c}$ ) may be sufficient to ensure zero profit without triggering a violation.

${ }^{22}$ Fifteen of the 20 largest users of H-1Bs are subcontractors and offshore outsourcing firms that place their temporary H-1B workers at another company's worksites, often for a short duration, to facilitate the offshoring of programming work (Hira 2016).

${ }^{23}$ Subcontracting is one of several instruments available to employers to adjust to changes in the external labor market: "primary employers, through devices such as subcontracting the temporary employment, can convert primary employment into secondary employment" (ibid, p. 272).
} 
mobility between markets is restricted to a certain degree: "[s]econdary workers cannot simply 'join' the primary labor market on an equal footing with those already there" (McDonald and Solow 1985, p. 1116). When unemployment is high, workers in the secondary market are especially unable to transition as they are at the end of the "queue" for hiring into the primary market (Doeringer and Piore 1971).

Dual labor market theory, as it applies to lead firms and subcontractors, can be understood in the context of the theoretical model via differences in workers' reservation wages between the two markets. Let $U^{s}$ and $U^{l}$ denote the reservation wages in the subcontractor ( secondary) and lead firm (primary) markets, where $U^{s}<U^{l}$ is implied by the preceding discussion. The threshold $k^{*}$, as defined in section 3.2.1, is therefore greater in the subcontractor market than in the lead firm market $\left(k_{l}^{*}<k_{s}^{*}\right)$. Thus, non-compliance is more prevalent in the subcontractor marker than in the lead firm market. Subcontractor employers, who systematically hire $\mathrm{H}-1 \mathrm{Bs}$ with lower reservation wages, face greater incentives to commit wage theft. Panel B of Figure 1 illustrates this graphically. The solid curve reproduces the $k^{*}(p)$ from Panel A (rescaling the vertical axis), though it now pertains to lead firms, for which $U^{l}=5$. The dashed curve graphs the $k^{*}(p)$ for subcontractor firms, for which $U^{s}=3$. The $k^{*}(p)$ curve for lead firms shifts to the northeast for subcontractors, thereby expanding the region of non-compliance.

\section{Data and Methods}

Two sources of micro-data (henceforth, the "demand-side data" and the "violations data") are used to analyze how economic conditions and labor market power affect violations. The “demand-side data" provide information on firms' labor demand for H-1Bs in a specific establishment from 2000 to $2017 .{ }^{24}$ The "violations data" provide firm-establishment information on the count of wage and hour violations a firm has in a labor market in years 2000 to 2017 , and the sum of the amount of wages owed to H-1Bs in a firm and labor market. ${ }^{25}$

\footnotetext{
${ }^{24}$ The Education and Training Administration's (ETA) Office of Foreign Labor Certification (OFLC), requires employers to submit an LCA, which registers the firm's desire to hire one or more H-1Bs in a particular location and occupation at a particular wage. The LCA data are available at https://www.dol.gov/agencies/eta/foreign-labor.

25 These data, which were obtained through a Freedom of Information Act request to the Department of Labor, are from the Wage and Hour Investigative Support and Reporting Database (WHISARD) and are maintained by the Wage and Hour Division (WHD) of the U.S. Department of Labor. As noted by Kerwin and McCabe (2011), state
} 
The demand-side data, the violations data and unemployment rates are combined into a matched dataset constructed at the firm, commuting zone, occupation, and year level. ${ }^{26}$ Section 4.1 describes each variable in the analysis. Section 4.2 summarizes descriptive statistics of the dataset. Section 4.3 presents statistical models used to analyze the data.

\subsection{Measures}

\subsubsection{Dependent Variables}

Number of Wage and Hour Violations

The main dependent variable is Violations, a count variable measuring the number of wage and hour violations against H-1Bs that the U.S. Department of Labor's Wage and Hour Division (WHD) determined were substantiated. This information is contained in the violations data, including the specific law (and section of the law) that was found to have been violated. Only the H-1B violations are retained. Whereas the demand-side data include yearly information on the occupations of H-1Bs sponsored, and information on the industry of a firm for several years, the violations data include information on the industry of every firm and no information on the occupation of H-1Bs. Industries are at the 2-digit, or sector, NAICS level. Thus, for years in which both the industry and the 2-digit Standard Occupational Classification (SOC) code are available, a matrix is constructed of the proportion of each occupation within an industry. Violations are then assigned proportionally to occupations according to the percentage of an occupation in an industry. For each violation recorded in the violations data, there is a start and end date. The matched dataset reflects that a violation occurred within a particular firm, year, occupation and commuting zone.

As seen in Table 1, violations are rare, with an average of 2.293 violations in the conditional fixed effects negative binomial model sample and 0.044 violations in the full sample.

\footnotetext{
wage and hour enforcement resources in the U.S. rival federal resources, so while a clear picture of wage violations for most workers using data from the federal Wage and Hour Division is unavailable, the H-1B program is an exception, given that all H-1B violations fall under federal purview. See Appendix B.

${ }^{26}$ The demand-side data set is constructed at the firm level but otherwise follows the process described in Gibbons et al. (2019). Matching involves cleaning firm names using algorithms that "stem" words that can have different spellings, such as "Incorporated" and "Inc." In addition to the firm matching procedure described in Wasi and Flaaen (2015), the authors hand-coded the largest 90 percent of employers to ensure continuity of naming conventions.
} 
Both panels reveal that Violations is an over-dispersed count variable (has a much larger variance than mean). In addition to negative binomial models that use Violations as the dependent variable, auxiliary OLS regressions are reported in the Appendix with transformations using $\log \left(1+1000\left(\frac{\text { Violations }_{f, o, c z, t}}{H 1 B s_{f, o, c z, t}}\right)\right)$ as the dependent variable. ${ }^{27}$

\section{Amount of Wage Theft}

An alternative dependent variable that captures the dollar amount of wage theft is the

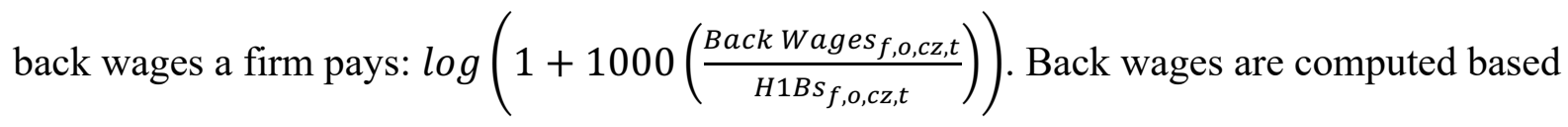
upon the amount of money that an employee was underpaid. Given the requirements for H-1Bs, an employer who is assessed back wages must have paid workers less than the promised or prevailing wage. Therefore, this is a direct measure of the substantiated amount of wage theft suffered by H-1Bs. As seen in Table 1, average back wages are $\$ 8690$ in the conditional firm fixed effects sample and $\$ 173$ in the full sample.

\subsubsection{Independent Variables}

\section{Economic Conditions and Labor Market Concentration}

Economic conditions are measured by the unemployment rate, $U R$, the percentage of unemployed workers in a commuting zone and year, from the Bureau of Labor Statistics (BLS) Local Area Unemployment (LAU) rate statistics. LAU statistics are available at the county-year level and are aggregated to the commuting zone-year and weighted by the size of the labor force in each county within a commuting zone. The unemployment rate is a percent, and as seen in Table 1, averages $6.22 \%$ in the conditional fixed effects negative binomial model sample and $6.02 \%$ in the full sample for the study period. To enable easier interpretation, the variable $U R$ is standardized in the regressions.

\footnotetext{
${ }^{27}$ Given that a matrix is used to proportionally assign violations to occupations, observations of Violations are rounded to the nearest integer in the negative binomial model that requires count data for the dependent variable. In the OLS regressions, the Violations variable is not rounded to the nearest integer.
} 
Labor market concentration is measured using the Herfindahl-Hirschman Index (HHI), which is constructed using annual disclosure data from the "demand-side" data filed by employers in the LCAs. ${ }^{28}$ Manning (2020) highlighted that studies must draw a boundary - using either industry or occupation - around a discrete labor market. In the present study, the demandside dataset is aggregated to the labor market level, defining labor markets by year, geographic region (commuting zone), and 2-digit SOC occupation code. For commuting zones, 1990 Census-defined geographical regions are used and are intended to describe local labor markets. The formula for $H H I$ is:

$$
H H I_{o, c z, t}=\sum_{i=1}^{n} s_{f, o, c z, t}^{2}
$$

where $s_{f, o, c z, t}^{2}$ is the share of firm $f^{\prime}$ 's employment in occupation $o$ and commuting zone $c z$ in year $t$. As described in section 5.5, the results are insensitive to defining the market with the alternative industry, commuting zone, and year level. To reduce noise, the three-year average HHI within a labor market is used. As noted in Manning (2020), a limitation of using HHI as a measure of labor market competitiveness is that even firms with many competitors may still enjoy market power due to frictions in the labor market that stand apart from concentration (such as imperfect information about available job opportunities). Mitigating this concern is the documented evidence of a positive correlation between concentration and lower wages. ${ }^{29} \mathrm{HHI}$ is scaled between 0 and 1, equaling 1 in a pure monopsony and 0 in an unconcentrated or competitive market. As seen in Table 1, the average $H H I$ is 0.149 in the conditional fixed effects negative binomial model sample and 0.142 in the full sample.

\section{Subcontractor Status}

In 2019, the Department of Labor's LCA data included information on whether a firm's H-1Bs were working directly for the firm that sponsored the worker (the "lead firm"), or for a

\footnotetext{
${ }^{28}$ These data include the number of $\mathrm{H}-1 \mathrm{Bs}$ sought, the occupation of the workers, and the geographic location.

${ }^{29}$ A rapidly growing literature suggests that diminished competition has a role in suppressing workers' wages (Azar et al. 2018; Benmelech, Bergman, and Kim 2020; Rinz, 2018; Hershbein and Macaluso 2018; Gibbons et al. 2019; Qiu and Sojourner 2019). Qiu and Sojourner (2019) studied how labor market concentration affects fringe benefits as well as wage levels, although most research that has focused on the effects of concentration has used wages as the dependent variable.
} 
secondary entity (the "subcontractor"). The names of both firms were reported. The data are coded as "Y = Workers will be placed with a secondary entity"; " $\mathrm{N}=$ Workers will not be placed with a secondary entity." A time invariant, firm-specific binary variable, $S U B$, is constructed equaling 1 if "Y" and 0 if "N." As seen in Table 1, 59.7\% of firms are subcontractors in the conditional fixed effects negative binomial model sample, and 7.1\% of firms are subcontractors in the full sample (when weighted by the number of H-1Bs employed, subcontractors employ $27.6 \%$ of $\mathrm{H}-1 \mathrm{Bs})$.

\subsubsection{Control Variables}

Control variables include demand-side data on the log of the number of $\mathrm{H}-1 \mathrm{Bs}$ for which LCAs were obtained within the labor market, $\log \left(H 1 B s_{f, o, c z, t}\right)$, and binary indicators for year, occupation, commuting zone, and firm. The log of the number of $\mathrm{H}-1 \mathrm{Bs}$ controls for the population at risk of experiencing a violation. Year indicators control for variation over time in H-1B policy, WHD enforcement strategy or resources, and potential selection issues arising in the WHISARD database due to investigations in progress not yet being included. Occupation indicators control for variation in the nature of work and the potential that H-1Bs employed in particular occupations may be at greater or lesser risk of wage theft.

Commuting zone indicators control for differences between geographical regions that might expose workers to a greater or lesser risk of wage theft, or differences in regional reporting of wage-theft incidents. The effect of concentration could reflect the existence of different types of firms in different labor markets. Several statistical models described in section 4.3 include firm-level fixed effects that control for time-invariant, unobserved, firm-level characteristics.

\subsection{Descriptive Statistics}

Table 1 reports descriptive statistics for all variables used in the analysis. The estimation sample, and therefore the sample size, differs considerably when the conditional fixed effects negative binomial model is estimated (see 4.3.1). That model drops many observations that lack within-firm variation in the outcome variable, leading to a sample that is different from the full sample: with more violations, higher back wages, and more subcontractors. Descriptive statistics are presented separately for the two samples, with the smaller sample (for models that include 
conditional firm fixed effects) in Panel 1a and the full sample in Panel 1b. As can be seen from Panel 1b, when looking at the full universe of firms that sponsor guest workers on visas, recorded wage and hour violations are a very sparse outcome, with only $0.004 \%$ of cells (approximately 5,600) at the firm, year, commuting zone, and occupation level having any violations.

Figure 2 (Figure 3) displays a bar graph of the average HHI (unemployment rate) for subcontractor and lead firms at "zero," "fewer than 5," and "6 or more" violations recorded. Figures 2 and 3 visually illustrate the main results of this study and the predictions of the model that: 1) wage and hour violations increase when the unemployment rate is higher, as modeled in section $3 ; 2$ ) wage and hour violations are higher in competitive markets than in monopsony markets, as modeled in section 3.2.1 and section 3.2.2; and 3) both effects are concentrated in subcontractor firms, as modeled in section 3.2.3.

Section 2 describes an effective $\$ 60,000$ wage floor for H-1B-dependent (largely subcontractor) firms that was put in effect after 2005. As a prima facie test of the validity of the theoretical model in the H-1B context, Figure 4 presents a kernel density estimate of the post2005 wage distributions for subcontractor and lead firms weighted by the number of H-1Bs. The figure demonstrates that subcontractors' wages are bunched near the applicable wage floor, whereas lead firms' wages show no such pattern.

\subsection{Statistical Models}

The five statistical models estimated in this study are described in the following five subsections. Models 1 and 2 are negative binomial count models because the dependent variable is an over-dispersed count of the number of violations. Models 3 and 4 are ordinary least squares (OLS) linear probability models and use $\log \left(1+1000\left(\frac{\left.{\text { Back } \operatorname{Wages}_{f, o, c z, t}}_{H 1 B s_{f, o, c z, t}}\right)}{\mathrm{O}}\right)\right.$ as the dependent variable. Model 5 is a probit model that summarizes the probabilities that a firm ever exits the labor market or commits a violation, and the probability that a firm exits or violates in a given year. The treatment of fixed effects in negative binomial models requires comment. As discussed in Cameron and Trivedi (2013), the fixed-effects model controls for firm-specific distributions of the dispersion parameter but is not a "true" fixed-effects model. The reason is that in a true fixed- 
effects model the coefficients of time-invariant regressors are not identified, whereas in the conditional fixed-effects negative binomial model they are. ${ }^{30}$ Henceforth, let $t, o, c z$, and $f$ index years, occupations, commuting zones, and firms, respectively.

\subsubsection{Model 1}

To estimate the effect of economic conditions and labor market power on wage and hour violations, the following conditional fixed-effects negative binomial regression model for panel data is estimated (Hausman, Hall, and Griliches 1984, Cameron and Trivedi 2013): ${ }^{31}$

$$
\begin{aligned}
& E\left[\text { Violations }_{f, o, c z, t}\right]= \\
& \quad \exp \left(\beta_{1} U R_{c z, t}+\beta_{2} H H I_{o, c z, t}+\alpha \alpha \log \left(H 1 B s_{f, o, c z, t}\right)+\delta_{f}+\mu_{o}+\gamma_{t}\right)
\end{aligned}
$$

where Violations $s_{f, o, c z, t}$ is the count of wage and hour violations within firm $f$ employing workers in occupation $o$ and commuting zone $c z$ in year $t$. The conditional fixed effect, $\delta_{f}$, applies only to the distribution of the dispersion parameter, so that all observations in the same firm have the same dispersion. ${ }^{32}$

The parameters of interest are $\beta_{1}$ and $\beta_{2}$. When exponentiated, they reflect incidence rate ratios, meaning that $\exp \left(\beta_{1}\right)$ measures the effect of an increase of one standard deviation (above the average) in the unemployment rate in a commuting zone in a given year, whereas $\exp \left(\beta_{2}\right)$ measures the effect of moving from a competitive market $(H H I=0)$ to a monopsony market $(H H I=1)$. The statistics $100 \exp \left(\beta_{1}\right)$ and $100 \exp \left(\beta_{2}\right)$ reflect percentage changes in the expected count of the dependent variable when the appropriate independent variable increases by one.

\footnotetext{
${ }^{30}$ However, true fixed effects can be incorporated into the model via a full set of unit-specific indicator variables.

${ }^{31}$ This statistical model has the following general form: $E\left[y_{i t}\right]=\exp \left(\delta_{i}+\beta x_{i t}\right)$, where the dependent variable $y_{i t}$ varies over units $i$ and time $t, x_{i t}$ refers to a single explanatory variable, $\beta$ is the parameter of interest to be estimated, and the conditional fixed effect is $\delta_{i}$. The $\delta_{i}$ term affects the mean and variance directly, while $x_{i t}$ affects the variance only through the mean (Allison and Waterman, 2002). The conditional fixed effect, $\delta_{i}$, applies only to the distribution of the dispersion parameter and not the $\beta x_{i t}$ term. In the more general case of more than one covariate, $\beta x_{i t}$ could be redefined in vector notation.

${ }^{32}$ The model is estimated using STATA's $x t n b r e g$ command. Standard errors are bootstrapped.
} 
The controls $\mu_{o}$ and $\gamma_{t}$ are a full set of occupation-and-year-specific indicator variables, whereas $\alpha \log \left(H 1 B s_{f, o, c z, t}\right)$ measures population exposure and reflects the log of the number of H-1Bs for which a firm obtained LCAs. Estimation results from negative binomial regressions for Model 1 are reported in Table 2 of section 5.1. Results that treat $\delta_{f}$ as a fixed effect are reported in Panel A, and those that treat it as a random effect are reported in Panel B.

\subsubsection{Model 2}

Model 2 is the following negative binomial regression: ${ }^{33}$

$$
\text { E } \left._{\text {Violations } \left._{f, o, c z, t}\right]}\right]=\exp \left(\beta_{1} U R_{c z, t}+\beta_{2} H H I_{o, c z, t}+\beta_{3} S U B_{f}+\right.
$$

$\left.\beta_{4}\left(S U B_{f} \times H H I_{o, c z, t}\right)+\beta_{5}\left(S U B_{f} \times U R_{c z, t}\right)+\mu_{o}+\gamma_{t}+\theta_{c z}+\alpha \log \left(H 1 B s_{f, o, c z, t}\right)\right)$

Model 2 incorporates additional independent variables that were absent from Model 1, in particular $S U B_{f}$ and its interactions with $H H I_{o, c z, t}$ and $U R_{c z, t}$. Control variables match those in Model 1 , except for the inclusion of commuting zone effects, $\theta_{c z}$, and the exclusion of firm effects, $\delta_{f}$.

Estimation results from Model 2 are reported in Table 3 of section 5.2. To interpret those results, note that the baseline odds are for a lead (non-subcontractor) firm in a competitive labor market with average unemployment, holding other controls constant. The change in the odds for a one-standard-deviation-above-average unemployment rate compared to the baseline is given by $\exp \left(\beta_{1}\right)$. The change in the odds for a monopsony market compared to the baseline is given by $\exp \left(\beta_{2}\right)$. The change in the odds for a subcontractor compared to the baseline is given by $\exp \left(\beta_{3}\right)$.

Multiplying the exponentiated coefficients of the main effects and their interaction terms yields the change in the odds when the main effects and their interaction are equal to 1 compared

\footnotetext{
${ }^{33}$ The STATA program $n b r e g$ is used to estimate the model. Standard errors are bootstrapped. Analysis categories are constructed following the procedure described in Silva and Tenreyro (2011), which drops indicator variables for specific occupations and commuting zones to create larger indicators when the smaller categories perfectly predict the outcome variable.
} 
to the baseline, which offers a more meaningful interpretation than marginal effects that rely on discrete values. ${ }^{34}$ Thus, the change in the odds for a subcontractor in a monopsony labor market at average unemployment compared to the baseline lead firm in a competitive market with average unemployment is given by $\exp \left(\beta_{2}\right) \exp \left(\beta_{3}\right) \exp \left(\beta_{4}\right)$, or $\exp \left(\beta_{2}+\beta_{3}+\beta_{4}\right)$, multiplying the change in the odds for a monopsony, $\exp \left(\beta_{2}\right)$, by the change in the odds for a subcontractor, $\exp \left(\beta_{3}\right)$, by the change in the odds of subcontractor between monopsony and competitive labor markets, $\exp \left(\beta_{4}\right)$.

The change in the odds for a subcontractor in a competitive labor market with a onestandard-deviation-above-average unemployment rate compared to the baseline lead firm in a competitive market with average unemployment is given by $\exp \left(\beta_{1}\right) \exp \left(\beta_{3}\right) \exp \left(\beta_{5}\right)$, or $\exp \left(\beta_{1}+\beta_{3}+\beta_{5}\right)$, multiplying the change in the odds for a one-standard-deviation-aboveaverage unemployment rate, $\exp \left(\beta_{1}\right)$, by the change in the odds for a subcontractor, $\exp \left(\beta_{3}\right)$, by the change in the odds of subcontractor between a one-standard-deviation-above-average unemployment and average unemployment, $\exp \left(\beta_{5}\right)$.

\subsubsection{Model 3}

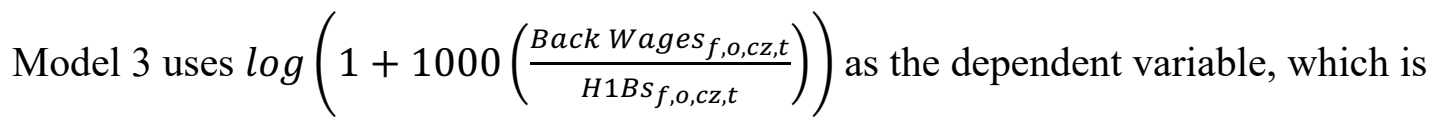
based on the dollar amount of back wages owed by a firm $f$ employing workers in occupation $o$ and commuting zone $c z$ in year $t$. The following regression is estimated by ordinary least squares (OLS) with robust standard errors:

$$
\log \left(1+1000\left(\frac{\text { BackWages }_{f, o, c z, t}}{H 1 B s_{f, o, c z, t}}\right)\right)=\beta_{0}+\beta_{1} U R_{c z, t}+\beta_{2} H H I_{o, c z, t}+\delta_{f}+\mu_{o}+\gamma_{t}+
$$

$\alpha \log \left(H 1 B s_{f, o, c z, t}\right)+\varepsilon_{f, o, c z, t}$

where $\beta_{1}$ and $\beta_{2}$ are the parameters of interest and $\varepsilon_{f, o, c z, t}$ is a stochastic disturbance term satisfying the usual properties.

\footnotetext{
${ }^{34}$ See Buis (2010).
} 
In Model 3, $\beta_{1}$ reflects the effect of a one-standard-deviation increase (above the average) in the unemployment rate, whereas $\beta_{2}$ reflects the effect on the log of back wages of moving from a competitive labor market $\left(H H I_{o, c z, t}=0\right)$ to a monopsony $\left(H H I_{o, c z, t}=1\right)$. A full set of indicators for firms, $\delta_{f}$, occupations, $\mu_{o}$, and years, $\gamma_{t}$, are included. Estimation results for Model 3 are reported in Panel A of Table 4 in section 5.3. For comparison, Panel B reports estimation results when firm indicators are excluded.

\subsubsection{Model 4}

Model 4 augments Model 3 with additional covariates, namely $S U B_{f}$ (the inclusion of which requires omitting the firm effect, $\delta_{f}$, from the model) and its interactions with $U R_{c z, t}$ and $H H I_{o, c z, t}$ Table 5 in section 5.4 reports OLS estimation results for the following Model 4.

$$
\begin{aligned}
& \text { (4) } \log \left(1+1000\left(\frac{\left.{\text { Back } \operatorname{Wages}_{f, o, c z, t}}_{H 1 B s_{f, o, c z, t}}\right)}{}\right)=\beta_{0}+\beta_{1} U R_{c z, t}+\beta_{2} H H I_{o, c z, t}+\beta_{3} S U B_{f}+\right. \\
& +\beta_{4} S U B_{f} H H I_{o, c z, t}+\beta_{5} S U B_{f} U R_{c z, t}+\mu_{o}+\gamma_{t}+\theta_{c z}+\alpha \log \left(H 1 B s_{f, o, c z, t}\right)+\varepsilon_{f, o, c z, t}
\end{aligned}
$$

Consider the effect on the dependent variable of a one-standard-deviation increase in $U R_{c z, t}$ (above its average value), in a competitive labor market (when $H H I_{o, c z, t}=0$ ). That effect is $\beta_{1}$ in lead firms (when $S U B_{f}=0$ ) and $\beta_{1}+\beta_{5}$ in subcontractor firms (when $S U B_{f}=1$ ). Next consider the effect on the dependent variable of a shift from a competitive market $\left(H H I_{o, c z, t}=0\right)$ to a monopsony $\left(H H I_{o, c z, t}=1\right)$ when the unemployment rate remains at its average. That effect is $\beta_{2}$ in lead firms and $\beta_{2}+\beta_{4}$ in subcontractor firms. Finally, consider the effect on the dependent variable of a shift from lead firm status to subcontractor status when the unemployment rate remains at its average. That effect is $\beta_{3}+\beta_{4}$ in a monopsony market and $\beta_{3}$ in a competitive labor market, whereas it is $\beta_{3}+\beta_{5}$ in a competitive labor market if the unemployment rate is one standard deviation above its average. 


\subsubsection{Model 5}

Section 3.2.2. predicts that firms in more competitive markets not only have more violations than firms in monopsony markets, they also are more likely to exit the market. To analyze the probability that a firm exits the market or has a violation the data are aggregated to the firm level. $H H I$ and $U R$ are weighted by the number of H-1Bs. Given that many firms appear for only one or two years in the data, the following analysis focuses on the subset of firms that has observations for at least 4 consecutive years. EverExit is a dummy variable equaling 1 if the firm ever drops out of the H-1B labor market, and 0 otherwise. EverViol is a dummy variable equaling 1 if the firm ever commits a violation, and 0 otherwise. The following probit model is estimated for both dependent variables, EverExit and EverViol:

$$
\operatorname{Pr}\left(\text { EverExit }=1 \mid \beta_{1} U R, \beta_{2} H H I, \log (H 1 B s)\right)=\phi\left(\beta_{0}+\beta_{1} U R+\beta_{2} H H I+\right.
$$
$\log (H 1 B s))$

The data are also aggregated at the firm-year level. $H H I$ and $U R$ are weighted by the number of H-1Bs. The dependent variable, Exit $t_{i}$, which is only defined if firm $i$ is present in the data set for at least four consecutive years, equals 1 if firm $i$ dropped out of the data set in year $t$ or if it dropped out of the data set in year $t+1$, and otherwise it equals 0 . At the firm-year level, the following probit model is estimated for firm exits, where Year $_{t}$ is a dummy variable equaling 1 in year $t$ and 0 otherwise:

$$
\begin{array}{r}
\operatorname{Pr}\left(\text { Exit }_{i t}=1 \mid \mathbf{X} \boldsymbol{\beta}\right)=\phi\left(\beta_{0}+\beta_{1} U R_{i, t-2}+\beta_{2} H H I_{i, t-2}+\right. \\
\left.\log \left(1+H 1 B s_{i, t-2}\right)+\text { Year }_{t}\right)
\end{array}
$$

The independent variables $(H H I, U R)$ and control variable $\log (1+H-1 B)$ are each lagged two years. Thus, changes in these variables in year $t-2$ are mapped to changes in the exit probability in the subsequent two years $(t-1$ and $t)$ in the empirical model.

With the same data at the firm-year level, a violation $\left(\right.$ Violation $\left._{i t}=1\right)$ is defined as having occurred if firm $i$ has one or more recorded violations in year $t$, with the variable equaling 0 otherwise. The following probit model is estimated for firm $i$ 's violations in year $t$ : 


$$
\begin{gathered}
\operatorname{Pr}\left(\text { Violation }_{i t}=1 \mid \boldsymbol{X}_{\boldsymbol{i t}} \boldsymbol{\beta}\right)=\phi\left(\beta_{0}+\beta_{1} U R_{i, t-1}+\beta_{2} H H I_{i, t-1,}+\right. \\
\left.\log \left(1+H 1 B s_{i, t-1}\right)+\text { Year }_{t}\right)
\end{gathered}
$$

Predicted marginal effects that exit or a violation ever occurred are reported in Panel A of Table 6. Predicted probabilities that exit or a violation ever occurred are reported in Panel A of Table 7 at critical values of $U R(0,1)$ and $H H I(0,1)$. Marginal effects and probabilities that exit or violation occurred in a given year are reported in Panel B of Tables 6 and 7, respectively, where the marginal effects are evaluated at the means of all variables. Results weighted by the number of $\mathrm{H}-1 \mathrm{Bs}$ and unweighted results are reported. Figure 5 illustrates the unweighted results.

\section{Estimation Results}

The next five sections report estimation results for each of the four statistical models described in section 4.3. Section 5.6 then summarizes the results of sensitivity analyses, and section 5.7 discusses limitations of the analysis.

\subsection{Model 1}

Table 2's Panel A reports results from estimation of Model 1 treating $\delta_{f}$ as a fixed effect. Recall from section 4.3.1 that the exponentiated coefficients measure the proportional change in the count of violations. The following pattern is revealed: 1) given that the exponentiated coefficients of $U R$ exceed 1, wage and hour violations are more likely in markets with higher unemployment rates; and 2) given that the exponentiated coefficients of $H H I$ are less than 1 , wage and hour violations are less likely in a pure monopsony than in a competitive labor market. In column (4) of Panel A, which reports the results based on the richest set of controls, the effect of a one standard deviation increase in the unemployment rate is a $13.8 \%$ increase in the count of violations, and the average effect of moving from a labor market with no concentration to a monopsony market is a $54 \%$ decrease in the count of violations.

Table 2's Panel B reports estimation results for Model 1 treating $\delta_{f}$ as a random effect. In column (4) of Panel B, the effect of a one standard deviation increase in the unemployment rate is a $16.6 \%$ increase in the count of violations, and the average effect of moving from a labor market with no concentration to a monopsony market is a $51 \%$ decrease in the count of 
violations. Panels A and B are similar, revealing that whether the individual firm effect, $\delta_{f}$, is treated as a fixed or random is not of major consequence for the results of interest. In both Panels $\mathrm{A}$ and $\mathrm{B}$, the effect of $\log (H-1 B s)$ is positive, as anticipated, which simply states that more $\mathrm{H}-$ 1 Bs are associated with more violations. Table 2's bottom line is that a worsening of economic conditions is associated with more violations, whereas an increase in concentration is associated with fewer violations. Those empirical results are consistent with section 3's theoretical model.

\subsection{Model 2}

Table 3 reports results from estimation of Model 2 from section 4.3.2. The main effect of economic conditions that was reported in Model 1 continues to hold in Model 2: in all eight specifications, as economic conditions worsen, the incidence of violations increases; seven of

these results are statistically significant at $p \leq 0.10$. Several new empirical results emerge as well: 1) across the specifications, subcontractors are much more likely to have wage and hour violations, 2) the negative effect of monopsony on violations is statistically insignificant for lead firms following the inclusion of the firm-level subcontractor variable and interactions, 3 ) subcontractors are much less likely to have wage and hour violations when the labor market is monopsonistic than when it is perfectly competitive, and 4) independent of the main effect of unemployment rates, subcontractors are more likely to have wage and hour violations in a higher unemployment rate environment.

Turning attention to the fullest set of controls in column (8) with indicators for year, occupation, and commuting zone, the effect of a one-standard-deviation increase in the unemployment rate is a $19.5 \%$ increase in the count of violations, the effect of concentration is statistically insignificant for lead firms, and the effect of being a subcontractor is a $1526 \%$ increase in the count of violations compared to the baseline case of a lead firm in a competitive market at average unemployment. Interaction terms reveal that a subcontractor in a monopsony is expected to have $91 \%$ fewer violations than a subcontractor in a competitive market would have. A subcontractor in a labor market with a one-standard-deviation increase in the unemployment rate is expected to have an increase in the rate of violations of $24.3 \%$ compared to non-subcontractors. Interpreting these results in light of the theoretical model's predictions, subcontractor firms have greater incentive to commit wage theft than lead firms, and in these 
firms in particular, the model's predicted effects of economic conditions and concentration are particularly strong. ${ }^{35}$ The interaction terms add nuance to the story: much of the main effect of labor market power occurs through subcontractor firms. A possible explanation is discussed in the conclusion.

\subsection{Model 3}

Table 4's Panel A reports results from estimation of Model 3. Panel A provides a withinfirm estimate of the log of the amount of back wages owed, rather than a count of the number of wage and hour violations. Several patterns found in Table 2 are repeated: 1) back wages are higher in markets with higher unemployment rates, and 2) back wages are lower in a pure monopsony compared to a competitive labor market. As seen in column (4) of Panel A, the expected effect of moving from a labor market with no concentration to a monopsony is a $2.15 \%$ decrease in back wages per $1000 \mathrm{H}-1 \mathrm{Bs}$, and the effect of one-standard-deviation increase in the unemployment rate is a $0.63 \%$ increase in back wages per $1000 \mathrm{H}-1 \mathrm{Bs}$.

Panel B reports results from estimation of Model 3 dropping the firm-specific indicators. The results are consistent with Panel A, demonstrating that the results of interest do not rely on within-firm analysis. Results are consistent across the 4 specifications of Panel A and the 4 specifications of Panel B. Results are consistent with the estimates presented in Table 2 and with the theoretical model in section 3 .

\subsection{Model 4}

Table 5 reports results from estimation of Model 4 of section 4.3.4. Recall that it augments Model 3 to add the commuting zone control, the subcontractor indicator, the interaction between the subcontractor indicator and $H H I$, and the interaction between the subcontractor indicator and the unemployment rate. The main effect of $U R$ on back wages is positive in all eight specifications and is statistically significant at $p \leq 0.02$ in six specifications. The main effect of $S U B$ is positive, significant, and stable across the eight specifications. The

\footnotetext{
${ }^{35}$ One possible explanation for this result is that subcontractors and firms in more competitive markets face a higher probability of being caught engaging in wage theft.
} 
main effect of $H H I$ is unstable and oscillates between negative and positive in the eight specifications, while the interaction between the subcontractor indicator and $H H I(U R)$ is negative (positive), significant, and stable.

In column (8) with the richest set of controls, the effect of a one-standard-deviation increase in the unemployment rate is a non-significant $0.24 \%$ increase in back wages per 1000 $\mathrm{H}-1 \mathrm{Bs}$ in lead firms. A lead firm is expected to owe a non-significant $0.23 \%$ more in back wages

per $1000 \mathrm{H}-1 \mathrm{Bs}$ in a monopsony market compared to a competitive market. A subcontractor firm owes $20.1 \%$ more per $1000 \mathrm{H}-1 \mathrm{Bs}$ than a lead firm in a competitive labor market at average unemployment. The interaction terms reveal that a subcontractor in a monopsony is expected to owe $4.7 \%\left(\beta_{3}+\beta_{4}\right)$ less in back wages per $1000 \mathrm{H}-1 \mathrm{Bs}$ than a subcontractor in a competitive market. A subcontractor in a competitive labor market with a one-standard-deviation increase in the unemployment rate is expected to have an increase in back wages of $22 \%\left(\beta_{3}+\beta_{5}\right)$ per 1000 $\mathrm{H}-1 \mathrm{Bs}$ compared to a subcontractor in a competitive labor market with average unemployment. As above, the main effect occurs through the subcontractor variable, and a possible explanation is discussed in the conclusion.

\subsection{Model 5: Firm Exits and Violations}

Table 6 reports the unweighted (columns 1 and 2) and population-weighted (columns 3 and 4) marginal effects at the mean of a one-unit increase in the predictors, $U R$ and $H H I$, on the probability that a firm exits the sample (columns 1 and 3) or that a firm has a violation (columns 2 and 4). Table 7 reports the probability of exit and violations at critical values of $H H I(0,1)$ and $U R(0,1)$. Panel A of each table reports probabilities for a firm that ever exits or has a violation, and Panel B reports probabilities that a firm exits or has a violation in a given year, based upon the prior year's $H H I$ and $U R$. Figure 5 illustrates that: 1) probability of exit or violation is consistently higher when $U R$ is one standard deviation above the mean, 2) as $H H I$ increases, the probability of exit or violation decreases.

\subsection{Sensitivity Analysis}

The main results from Models 1 and 2 use Violations as a dependent variable only in a negative binomial model, rely on a single definition of the relevant labor market, and are 
unweighted. Appendix Tables A.1 through A.6 provide estimates that check whether the results are sensitive to the transformation of the dependent variable, the choice of negative binomial or linear probability model, the weighting scheme, or the definition of the relevant labor market at a granular or aggregated occupational (or industry) level. The present section discusses these results that are presented in the Appendix.

Tables A.1 and A.2 in Appendix 1 repeat the analysis in Tables 2 and 3 using OLS on the alternative $\log \left(1+1000\left(\frac{\text { Violations }_{f, o, c z, t}}{H 1 B s_{f, o, c z, t}}\right)\right)$, as was used in the Marinescu, Qiu, and Sojourner (2021) analysis. In the linear probability models, the dependent variable is not rounded to the nearest integer as was done to produce the dependent variable for the count models. Results with the alternative dependent variable and the linear probability model are similar to results obtained from the negative binomial model.

Weighting is another consideration. The main estimates are unweighted and represent the effect on Violations in a firm in a labor market as the unit of analysis. Given that the firm makes the decision to violate or not violate wage and hour law, estimating the effect on whether an average firm has a wage and hour violation, rather than the effect on whether an average worker experiences a violation, is preferred in this study. Weighting yields a different interpretation than the unweighted analysis, involving the expected change in the count of violations for an individual H-1B worker, rather than the change expected for a firm, occupation, commuting zone, and year. Tables A.3 and A.4 report results that weight by the number of guest workers in a given firm in a labor market with dependent variables $\log \left(1+1000\left(\frac{\text { violations }_{f, o, c z, t}}{H 1 B s_{f, o, c z, t}}\right)\right)$ and

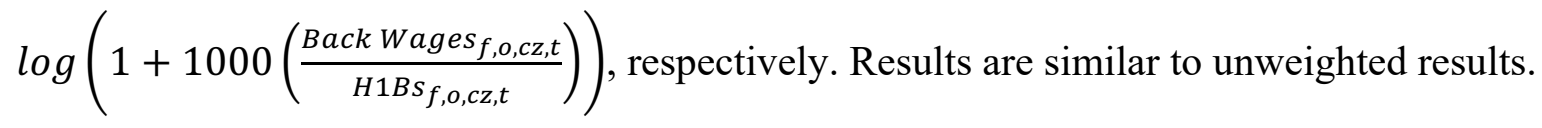

Given that these data are unusually comprehensive and allow a firm-level matched dataset and within-firm regressions, the main analyses here are more granular than analysis at the labor market level. However, given that other analyses may be reported at the labor market level, the dataset is aggregated, and results are presented at the labor market level in Tables A.5 and A.6. In both tables A.5 and A.6, the dependent variable Violations is at the labor market and year level, not at the firm, labor market, and year level. Negative binomial regressions with robust 
standard errors are estimated. Table A.5 uses a labor market defined at the year, commuting zone, and occupation level. Given the potential sensitivity of results to the definition of the labor market as described in section 4.1.2, Table A.6 uses a labor market defined at the year, commuting zone, and industry level. In Table A.6, the variable $H H I$ is calculated as

$$
H H I_{i, c z, t}=\sum_{i=1}^{n} s_{f, i, c z, t}^{2}
$$

where 2-digit NAICS code industry $i$ substitutes for occupation $o$. Results presented feature industry indicators instead of occupation. Results obtained at either the occupation or the industry labor market level are similar to the main firm-level analyses.

The analyses of Tables A.1 through A.6 demonstrate that results are not sensitive to the choice of negative binomial or OLS regression, weighted or unweighted analysis, level of aggregation, or industrial versus occupational definition of the relevant labor market.

\subsection{Limitations}

Under-reporting of violations is a concern that is not unique to the WHISARD data, and should be borne in mind when interpreting results. Evidence suggests that one wage and hour complaint is made for every 130 violations (Weil and Pyles, 2005). Another limitation is that the only observations in the violations data are the ones for which wage theft allegations were first reported to the WHD, then investigated, and then yielded a satisfactory conclusion. The resulting survivorship bias, in which only the firms that get caught are listed in the dataset, could tilt the results toward the firms that are unable to escape scrutiny. The possibility of survivorship bias notwithstanding, it remains the case that the WHISARD data are the most comprehensive data available on this subject. Moreover, guest workers represent a rare population - possibly the only population - for which the WHISARD data set is likely to contain the complete administrative record. Furthermore, examining the relationship within firm, as done here, suggests that this study's main result is robust to this concern.

\section{Conclusion}

The main results of this study are that increases in the unemployment rate are associated with more wage theft against $\mathrm{H}-1 \mathrm{Bs}$, whereas increases in the degree of labor market 
concentration are associated with less. Additionally, both effects are amplified in subcontractor firms, which themselves are more likely than lead firms to engage in wage theft. A theoretical framework is also introduced in which the preceding results can be interpreted.

The theoretical model offers insight concerning several recent or proposed changes to the H-1B program. A federal regulation first developed under the Trump administration and now being evaluated by the Biden administration would raise the prevailing wage requirement. Given that it would raise the prevailing wage at every experience level rather than just for the lowestpaid workers who are heavily concentrated in subcontractor firms, the proposed change could raise the prevailing wage more at lead than at subcontractor firms. Such a policy change could increase wage theft by removing more lead firms from the market for guest workers, and in fact, lead firms have increasingly been crowded out by a secondary labor market that specializes in obtaining scarce visas and then outsourcing H-1Bs' labor. Such a policy effect would run counter to the program's aim of attracting high-skill, high-wage workers in occupations experiencing shortages (Sharma and Sparber 2020).

One approach to counter the secondary labor market would raise the skill and prevailing wage requirements for the H-1B. A USCIS regulation in late 2020 (not implemented as of March 2021) would replace the lottery for H-1B visas with a ranking system based upon skill and wage. Contrary to ordinary intuition that raising wage floors would increase non-compliance (Clemens and Strain 2020), increasing skill and prevailing wage requirements for the H-1B program could increase compliance by decreasing the use of the program by subcontractors and by limiting the program to $\mathrm{H}-1 \mathrm{Bs}$ in occupations with lower unemployment rates (which tend to have higher wage and skill requirements). Raising the bottom of the wage floor for H-1Bs could lead lowwage subcontractor firms (whose wages are bunched around the $\$ 60,000$ floor) to drop out of program participation if wage costs are too high.

Another channel for increasing compliance that this study identifies is raising fines $k$ or lowering the critical threshold for violation, $k^{*}$. An unusual law prohibits the Department of Labor from engaging in proactive or strategic investigations of $\mathrm{H}-1 \mathrm{~B}$ employers unless the Department possesses "reasonable cause" for launching an investigation (see Appendix B). In light of that law, measures that make it easy (and personally advantageous) for workers to report wage theft could increase the probability, $p$, that non-compliant firms are caught. Those 
measures might include special visas for guest workers who report wage theft, education campaigns, targeted online advertising, and easy-to-submit complaints. Given that the H-1B program is small relative to both the size of the economy and the amount of wage theft, such a targeted online awareness campaign could serve as a pilot for a potential broad effort to increase compliance with wage and hour laws.

The theoretical framework and empirical results offer several additional insights into combatting wage theft generally. First, a tight labor market is less likely to be a market in which firms can underpay workers. Second, while monopsonies do lower wages, reducing monopsony power directly via anti-trust enforcement does not seem a promising route to reducing wage theft. Finally, while Weil (2018) attributes non-compliance in "fissured" workplaces to small margins in the product market, the present study's model and empirical results suggest an alternative explanation: non-compliance is increased by a dual labor market of workers (with low reservation wages) who are unable to leave the secondary sector of temporary, subcontractor, and staffing type firms. 


\section{References}

Abraham, Katherine G. 2015. Is skill mismatch impeding US economic recovery?. Industrial and Labor Relations Review 68(2): 291-313.

Allison, Paul D., and Richard P. Waterman. 2002. Fixed-effects negative binomial regression models. Sociological Methodology 32(1): 247-265.

Amior, Michael, and Alan Manning. 2020. Monopsony and the wage effects of migration. CEP Discussion Paper No. 1690, Centre for Economic Performance, London School of Economics, London, UK.

Ashenfelter, Orley, and Robert S. Smith. 1979. Compliance with the minimum wage law. Journal of Political Economy 87(2): 333-50.

Azar, José A., Ioana Marinescu, Marshall I. Steinbaum, and Bledi Taska. 2020. Labor market concentration. Journal of Human Resources. doi: 10.3368/jhr.monopsony.1218-9914R1

Benmelech, Efraim, Nittai K. Bergman, and Hyunseob Kim. 2020. "Strong employers and weak employees: How does employer concentration affect wages?." Journal of Human Resources. doi: 10.3368/jhr.monopsony.0119-10007R1

Bernhardt, Annette, Heather Boushey, Laura Dresser, and Chris Tilly. 2008. The gloves-off economy: Workplace standards at the bottom of America's labor market. Ithaca, NY: Cornell University Press.

Bernhardt, Annette, Ruth Milkman, Nik Theodore, Douglas D. Heckathorn, Mirabai Auer, James DeFilippis, Ana Luz González, Victor Narro, and Jason Perelshteyn. 2009. Broken laws, unprotected workers: Violations of employment and labor laws in America's cities. National Employment Law Project.

Bernhardt, Annette, Michael W. Spiller, and Nik Theodore. 2013. Employers gone rogue: Explaining industry variation in violations of workplace laws. Industrial and Labor Relations Review 66(4): 808-32.

Bobo, Kim. 2011. Wage theft in America: Why millions of working Americans are not getting paid and what we can do about it. The New Press.

Borjas, George, and Hugh Cassidy. 2019. The wage penalty to undocumented immigration. Labour Economics 61101757.

Bound, John, Breno Braga, , Joseph M. Golden, and Gaurav Khanna. 2015. Recruitment of foreigners in the market for computer scientists in the United States. Journal of Labor Economics 33(3), part 2, S187-S223.

Buis, Maarten L. 2010. Stata tip 87: Interpretation of interactions in nonlinear models. The Stata Journal, 10(2), 305-308.

Cameron, Colin A., and Pravin K. Trivedi. 2013. Regression analysis of count data (Second Edition). Cambridge University Press, New York, NY.

Cappelli, Peter H. 2015. Skill gaps, skill shortages, and skill mismatches: Evidence and arguments for the United States. Industrial and Labor Relations Review 68(2): 251-90.

Clemens, Jeffrey, and Michael R. Strain. 2020. Understanding "Wage Theft": Evasion and Avoidance Responses to Minimum Wage Increases. NBER Working Paper No. w26969. National Bureau of Economic Research, Cambridge, MA. 
Depew, Briggs, Peter Norlander, and Todd A. Sørensen. 2017. Inter-firm mobility and return migration patterns of skilled guest workers. Journal of Population Economics 30(2): 681721.

DeVaro, Jed. 2014. Stealing wages from immigrants. Compensation and Benefits Review 46: 96102.

DeVaro, Jed. 2020. Strategic compensation and talent management: Lessons for managers. Cambridge, England, U.K: Cambridge University Press.

Doeringer, Peter B., and Michael J. Piore.1971. Internal Labor Markets and Manpower Analysis. Lexington, MA, 1971.

Doran, Kirk, Alexander Gelber, and Adam Isen. 2014. The Effect of High-Skilled Immigration on Patenting and Employment: Evidence from H-1B Visa Lotteries. NBER Working Paper No. 20688, National Bureau of Economic Research, Cambridge, MA.

Dube, Arin. 2014. Proposal 13: Designing Thoughtful Minimum Wage Policy at the State and Local Levels. Policies to Address Poverty in America 137(7).

Fine, Janice, and Jennifer Gordon. 2010. Strengthening Labor Standards Enforcement through Partnerships with Workers' Organizations. Politics \& Society 38(4): 552-

85. https://doi.org/10.1177/0032329210381240

Fine, Janice, Daniel Galvin, Jenn Round, and Hana Shepherd. 2021. Wage Theft in a Recession: Unemployment, Labor Violations, and Enforcement Strategies for Difficult Times. Northwestern Institute for Policy Research Working Paper 21-09.

Gibbons, Eric M., Allie Greenman, Peter Norlander, and Todd A. Sørensen. 2019. Monopsony power and guest worker programs. Antitrust Bulletin, 64: 540-565. doi: $10.1177 \% 2 \mathrm{~F} 0003603 \mathrm{X} 19875040$.

Gleeson, Shannon. 2016. Precarious claims: The promise and failure of workplace protections in the United States. Oakland: University of California Press.

Griffith, Kati L. 2009. US migrant worker law: The interstices of immigration law and labor and employment law. Comparative Labor Law \& Policy Journal 31, 125.

Hatch, Orrin. 2000. American Competitiveness in the Twenty-First Century Act. Report of the Judiciary Committee. 106th Congress. See: https://www.congress.gov/congressionalreport/106th-congress/senate-report/260

Hausman, Jerry, Bronwyn H. Hall, and Zvi Griliches. 1984. Econometric models for count data with an application to the patents-R\&D relationship. Econometrica 52(4): 909.

Hershbein, Brad, and Claudia Macaluso. 2018. Labor market concentration and the demand for skills. Working paper.

Hira, Ronil 2016. The Impact of High-Skilled Immigration on U.S. Workers. Congressional testimony. February 25, 2016. The Subcommittee On Immigration And The National Interest Of The Judiciary Committee. U.S. Senate. Washington, D.C.

Hira, Ronil. 2017. Bridge to permanent immigration or temporary labor? The H-1B visa program is a source of both. In US Engineering in a Global Economy (pp. 263-283). Richard B. Freeman and Hal Salzman, editors. National Bureau of Economic Research. University of Chicago Press. 
Hunt, Jennifer. 2015. Are immigrants the most skilled US computer and engineering workers? Journal of Labor Economics 33(3), part 2, S39-S77.

Hunt, Jennifer, and Bin Xie. 2019. How restricted is the job mobility of skilled temporary work visa holders? Journal of Policy Analysis and Management 38(1): 41-64.

Ji, Minwoong, and David Weil. 2015. The impact of franchising on labor standards compliance. Industrial and Labor Relations Review 68(5): 977-1006.

Kerr, Sari P., Kerr, William R., and William F. Lincoln. 2015. Skilled immigration and the employment structures of US firms. Journal of Labor Economics 33(S1): S147-86.

Kerwin, Donald M., and Kristen McCabe. 2011. Labor standards enforcement and low-wage immigrants: Creating an effective enforcement system. Migration Policy Institute Washington, DC.

Manning, Alan. 2003. Monopsony in motion: Imperfect competition in labor markets. Princeton, NJ: Princeton University Press.

Manning, A. 2020. Monopsony in labor markets: a review. Industrial and Labor Relations Review.

Marinescu, Ioana, Yue Qiu, and Aaron Sojourner. 2021. Wage Inequality and Labor Rights Violations. NBER Working Paper No. w28475, National Bureau of Economic Research, Cambridge, MA.

McDonald, Ian M., and Robert M. Solow. Wages and employment in a segmented labor market. The Quarterly Journal of Economics 100(4): 1115-1141.

Naidu, Suresh, Yaw Nyarko, and Shing-Yi Wang. 2016. Monopsony power in migrant labor markets: evidence from the United Arab Emirates. Journal of Political Economy 124(6): 1735-92.

Norlander, Peter, and Varma, Arup. 2019. H-1B and L-1 visa-sponsored guest workers in the USA: An analysis of the strategic impact of Indian and other firms. Thunderbird International Business Review doi: 10.1002/tie.22044

Peri, Giovanni, Kevin Shih, and Chad Sparber. 2015. STEM workers, H-1B visas, and productivity in US cities. Journal of Labor Economics 33(3), part 2, S225-S255.

Qiu, Yue, and Aaron Sojourner. 2019. Labor-market concentration and labor compensation. Available at SSRN 3312197.

Rinz, Kevin. 2018. Labor market concentration, earnings inequality, and earnings mobility. Working Paper 10, Center for Administrative Records Research and Applications, Census Bureau, Washington, DC.

Rissing, Ben A., and Emilio J. Castilla. 2016. Testing attestations: US unemployment and immigrant work authorizations. Industrial and Labor Relations Review 69(5): 1081-1113.

Sharma, Rishi, and Chad Sparber, 2020. Buying Lottery Tickets for Foreign Workers: Search Cost Externalities Induced by H-1B Policy. IZA Discussion Paper No. 13892, IZA, Bonn, Germany.

Silva, João S., and Silvana Tenreyro. 2011. Poisson: Some convergence issues. The Stata Journal 11(2): 207-12. 
Sokolova, Anna, and Todd Sørensen. 2021. Monopsony in labor markets: A meta-analysis. Industrial and Labor Relations Review 74(1): 27-55.

Wasi, Nada, and Aaron Flaaen. 2015. Record linkage using stata: Preprocessing, linking, and reviewing utilities. The Stata Journal 15(3): 672-97.

Webber, Douglas A. 2015. Firm market power and the earnings distribution. Labour Economics 35:123-34.

Weil, David. 2005. Public enforcement/private monitoring: Evaluating a new approach to regulating the minimum wage. Industrial and Labor Relations Review 58(2): 238-57.

Weil, David. 2009. Rethinking the regulation of vulnerable work in the usa: A sector-based approach. Journal of Industrial Relations 51(3): 411-30.

Weil, David. 2012. Examining the underpinnings of labor standards compliance in low wage industries. Report to the Russell Sage Foundation.

Weil, D., 2018. Creating a strategic enforcement approach to address wage theft: One academic's journey in organizational change. Journal of Industrial Relations 60(3), pp.437-460.

Weil, David, and Amanda Pyles. 2005. Why complain-complaints, compliance, and the problem of enforcement in the US workplace. Comparative Labor Law \& Policy Journal 27, 59. 


\section{Figures}

\section{Figure Legends}

Figure 1 - WAGe-Setting Choices FACING The MonOPSONIST

Figure 2 - AvERAGE HHI AND THE COUNT OF Violations $(0, \leq 5,>6)$

Figure 3 - AVERAGe Unemployment RAte AND the Count of Violations $(0, \leq 5,>6)$

Figure 4 - Post-2005 KeRnel Density Estimate OF WAGES OfFERED BY SUBCONTRACTOR/LEAD FIRM STATUS

Figure 5 - PROBABILITIES A FIRM EXITS OR VIOLATES 


\section{Figure 1}

WAGe-Setting Choices FACING THE MonOPSONIST

PANEl A: Monopsony “COMPLiAnCE” AND “Non-COMPliance” Regions of $(p, k)$

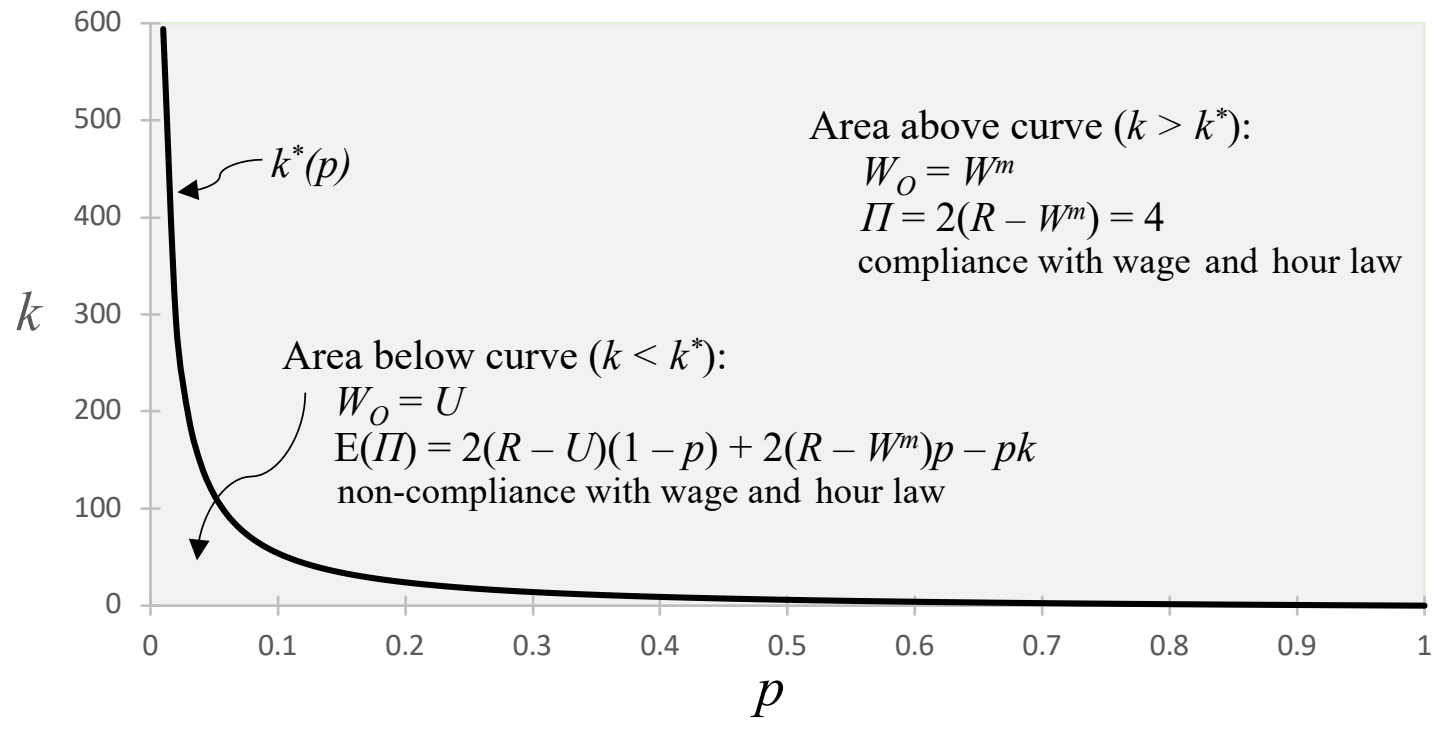

Note: $R=10, U=5, W^{m}=8$, solid curve is $k^{*}(p)=\frac{2\left(W^{m}-U\right)(1-p)}{p}$.

PANEL B: $k_{l}^{*}(p)$ FOR LEAD FIRMS AND $k_{s}^{*}(p)$ FOR SUBCONTRACTORS

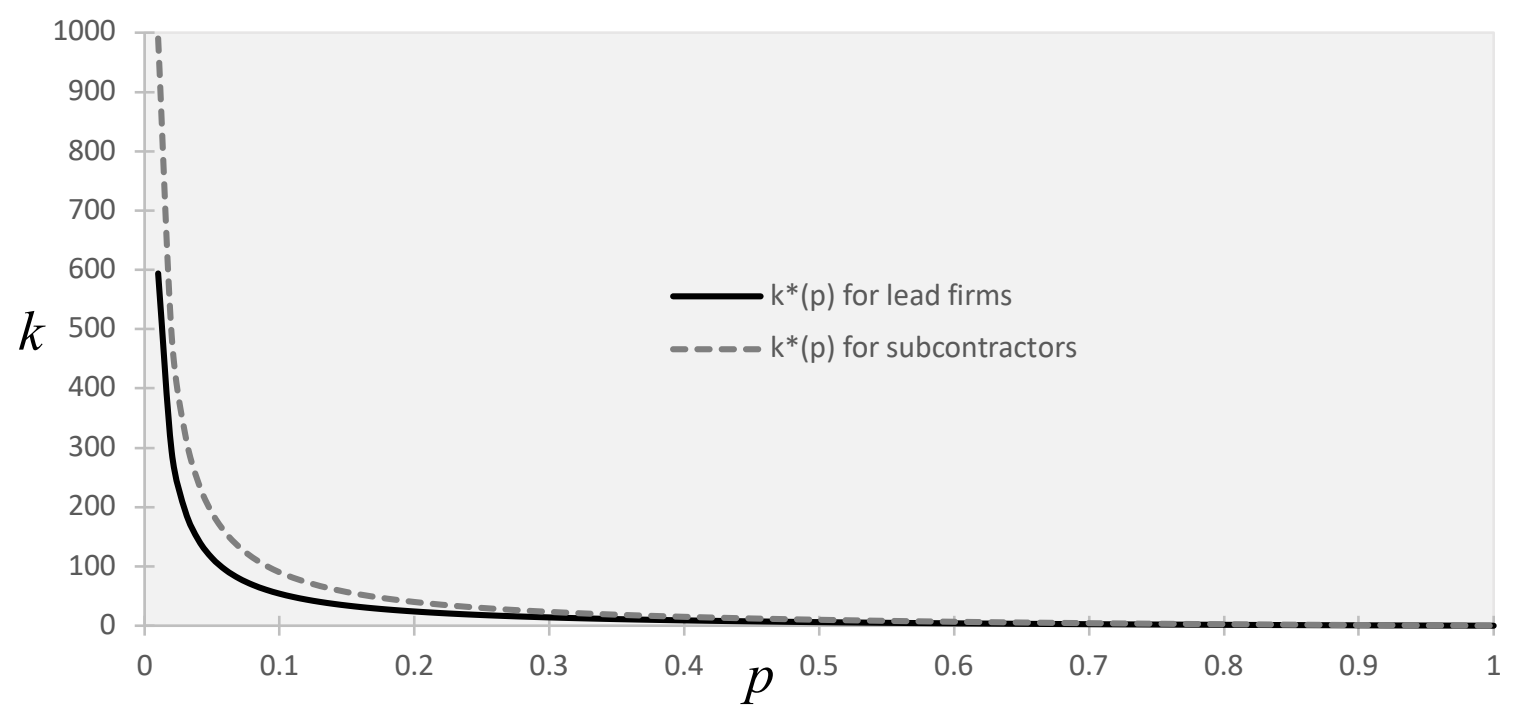

Note: $R=10, U^{l}=5, U^{s}=3, W^{m}=8, k_{s}^{*}(p)=\frac{2\left(W^{m}-U^{S}\right)(1-p)}{p}, k_{l}^{*}(p)=\frac{2\left(W^{m}-U^{l}\right)(1-p)}{p}$. Area above (below) a given curve is the compliance (non-compliance) region for that firm type. 
Figure 2

Average HHI AND THE COUNT OF Violations $(0, \leq 5,>6)$

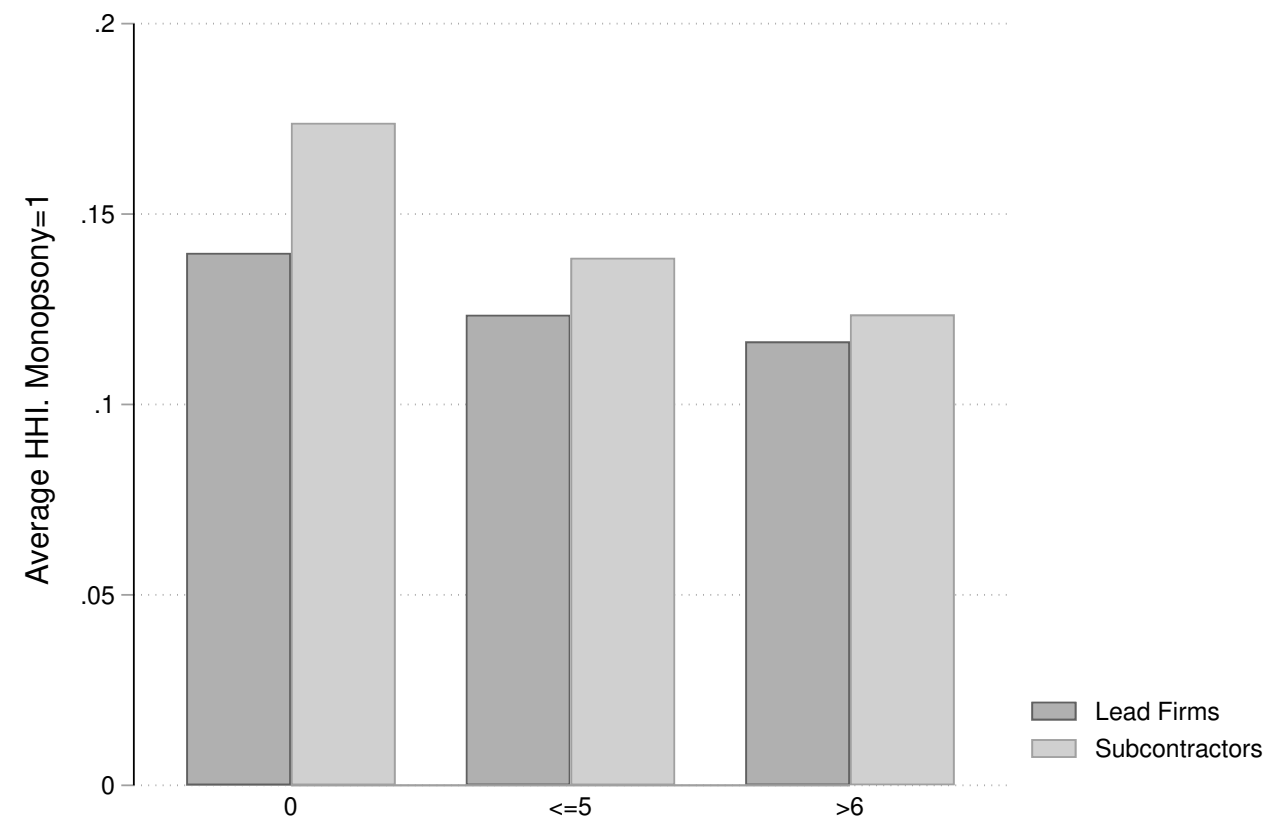

Figure 3

Average Unemployment Rate and the Count of Violations $(0, \leq 5,>6)$

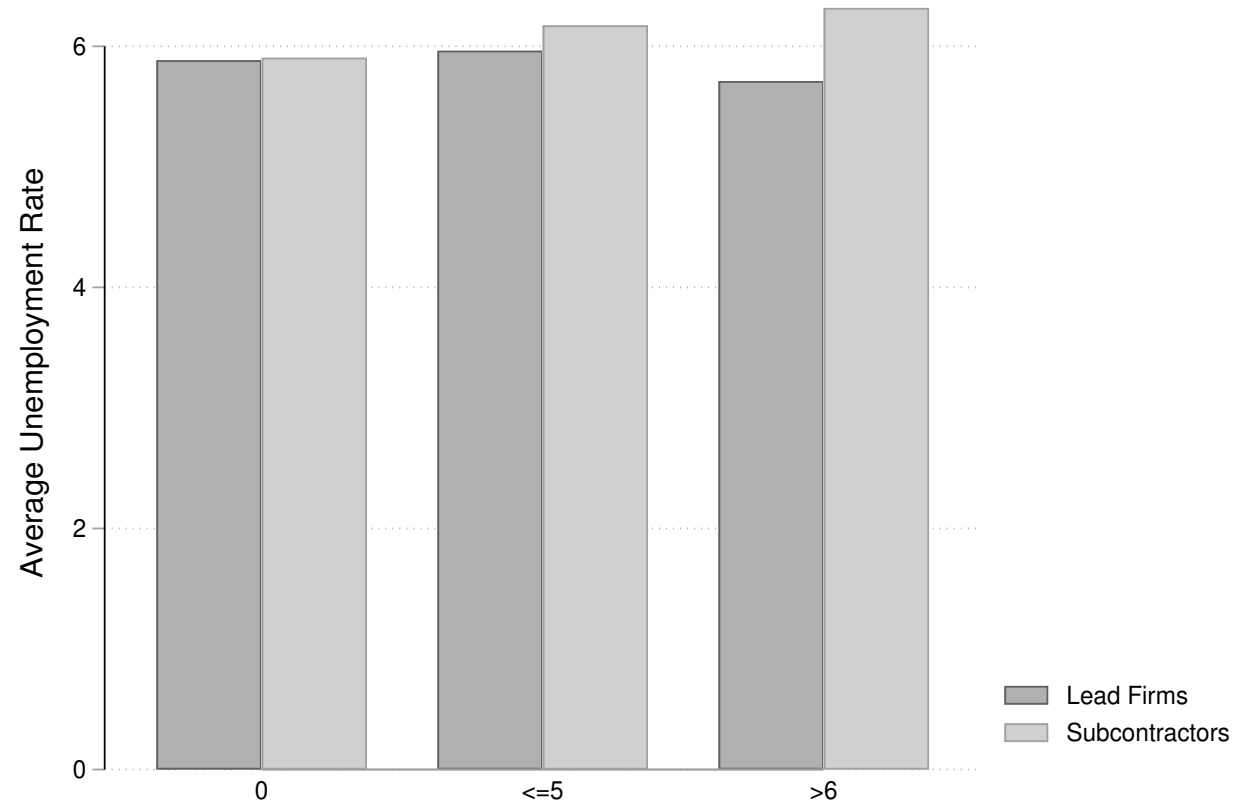




\section{Figure 4}

\section{Post-2005 Kernel Density Estimate OF WAges OfFEREd By SubCONTRACTOR/LEAD Firm STATUS}

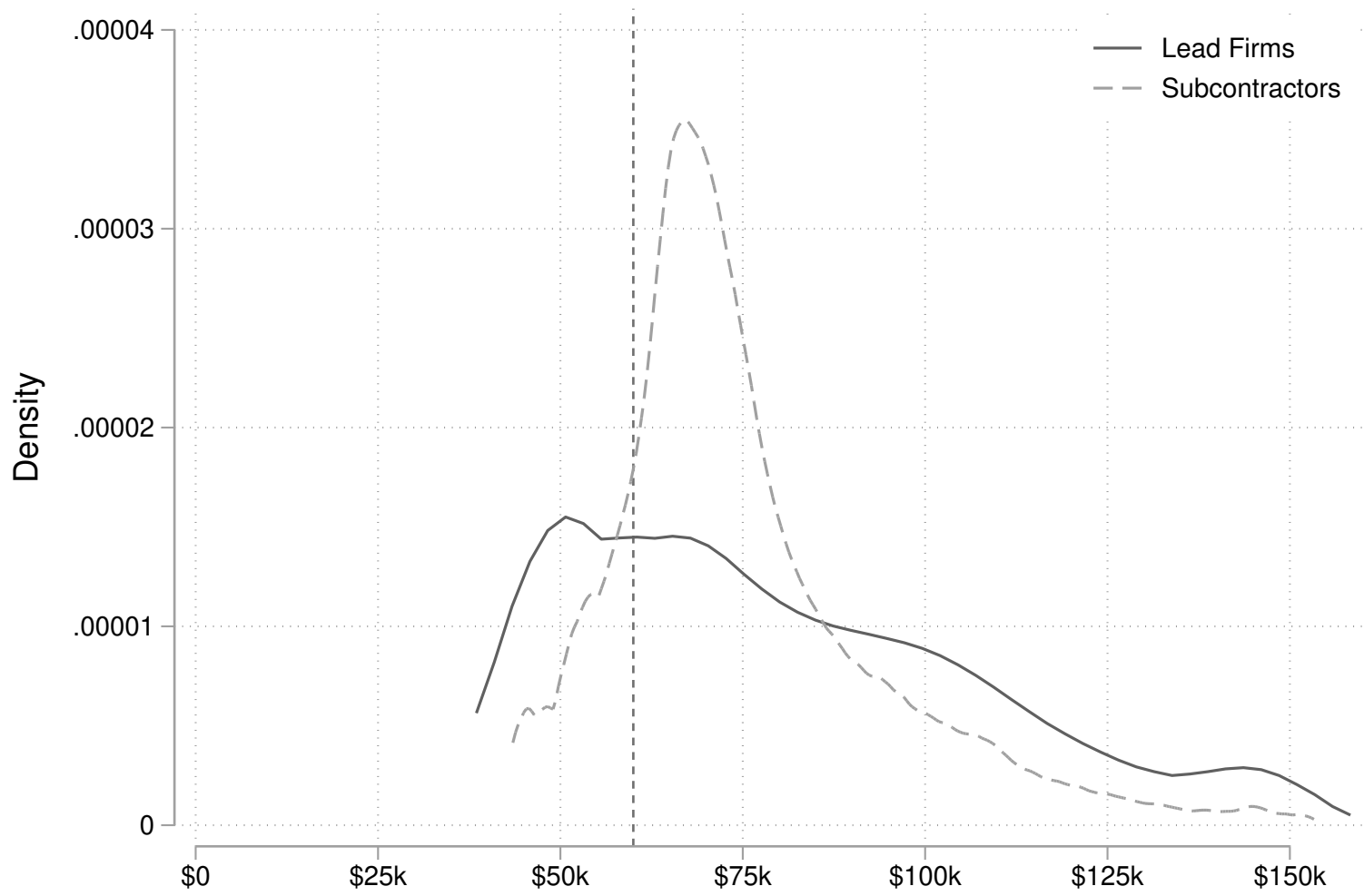

Note: Epanechnikov kernel with bandwidth $=\$ 5,000$. The vertical line at $\$ 60,000$ indicates the wage floor to avoid additional labor market tests for H-1B-dependent firms that was effective after Fiscal Year 2005. 


\section{Figure 5}

\section{Probabilities A FIRM EXITS OR VIOLATES}

Probability a Firm Exits

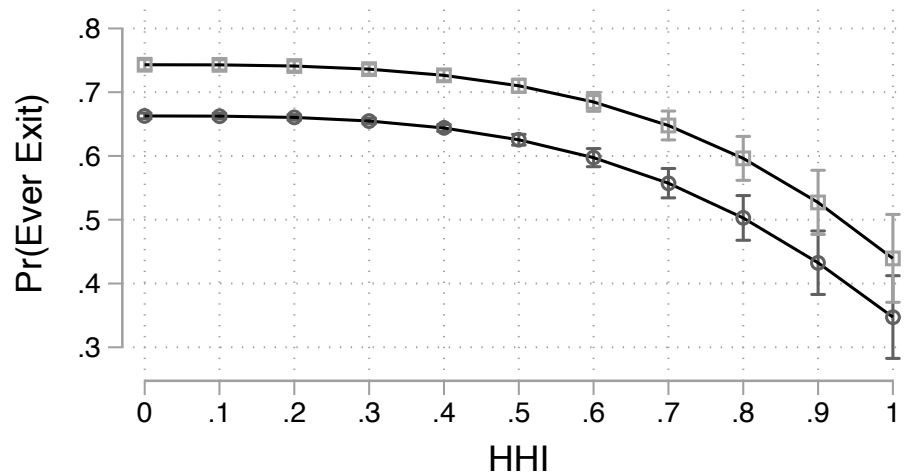

$\longmapsto 1 \mathrm{SD}+\mathrm{UR} \longmapsto$ Mean UR

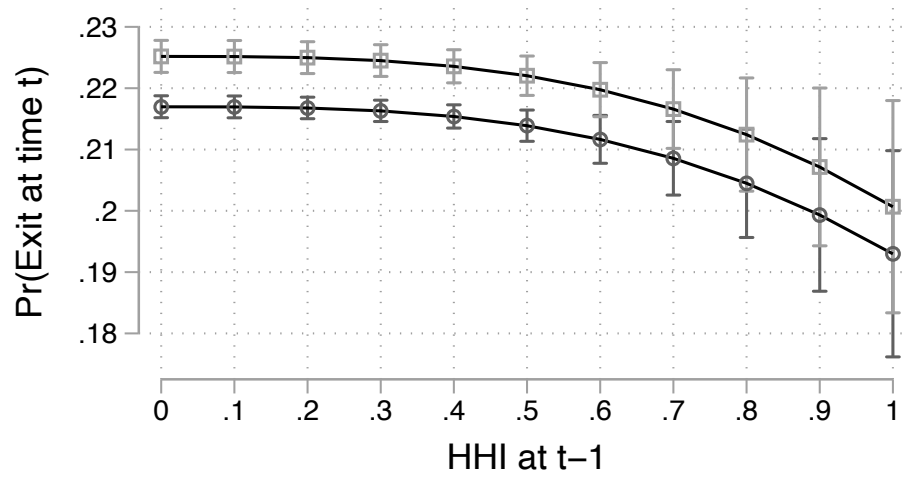

$\longmapsto 1 \mathrm{SD}+\mathrm{UR}(\mathrm{t}-1) \quad \longmapsto \quad$ Mean $\mathrm{UR}(\mathrm{t}-1)$
Probability a Firm Has a Violation

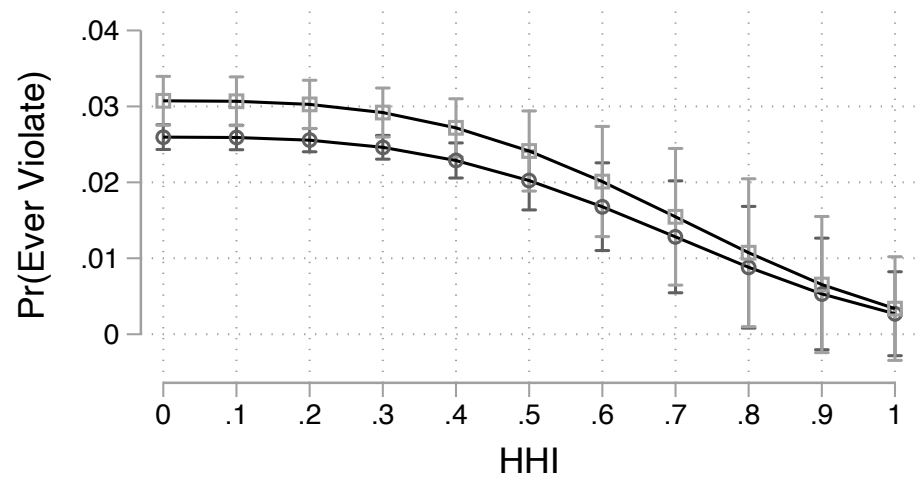

$\longmapsto 1 \mathrm{SD}+\mathrm{UR} \longmapsto$ Mean UR

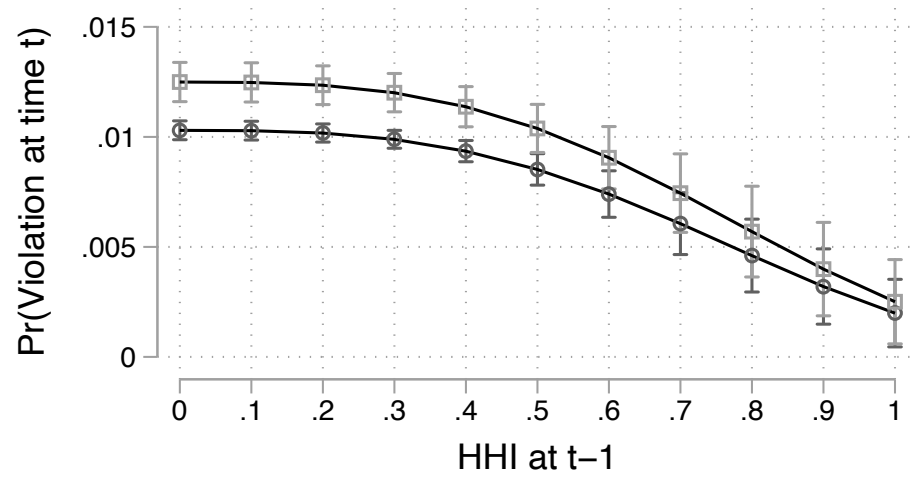

$\longmapsto 1 \mathrm{SD}+\mathrm{UR}(\mathrm{t}-1) \quad \longmapsto \quad$ Mean $\mathrm{UR}(\mathrm{t}-1)$ 
Table 1

DESCRIPTIVE STATISTICS

\begin{tabular}{|c|c|c|c|c|}
\hline \multicolumn{5}{|c|}{ 1a. Descriptive Statistics for Conditional Fixed Effects Sample (Table 1a) } \\
\hline & Mean & SD & Min & Max \\
\hline Violations & 2.293 & 15.197 & 0.000 & 485.000 \\
\hline$\%$ of Cells with any Violations & 0.201 & 0.400 & 0.000 & 1.000 \\
\hline Back Wages (\$) & $8,690.01$ & $68,682.85$ & 0.000 & $2,159,247.49$ \\
\hline Number of $\mathrm{H}-1 \mathrm{Bs}$ & 16.368 & 23.167 & 0.000 & 70.000 \\
\hline$H H I$ & 0.149 & 0.171 & 0.001 & 1.000 \\
\hline Unemployment Rate (UR \%) & 6.217 & 2.164 & 2.406 & 26.797 \\
\hline Standardized $U R$ & 0.095 & 1.050 & -1.755 & 10.083 \\
\hline Subcontractor (SUB) & 0.597 & 0.491 & 0.000 & 1.000 \\
\hline Observations & 25,683 & & & \\
\hline \multicolumn{5}{|c|}{ 1b. Descriptive Statistics for Full Sample (Tables 1b - Model 4) } \\
\hline & Mean & SD & Min & Max \\
\hline Violations & 0.044 & 2.118 & 0.000 & 484.698 \\
\hline$\%$ of Cells with any Violations & 0.004 & 0.064 & 0.000 & 1.000 \\
\hline Back Wages & 172.946 & $9,570.912$ & 0.000 & $2,159,247.49$ \\
\hline Number of $\mathrm{H}-1 \mathrm{Bs}$ & 3.509 & 9.124 & 0.000 & 70.000 \\
\hline$H H I$ & 0.142 & 0.190 & 0.001 & 1.000 \\
\hline Unemployment Rate (UR\%) & 6.022 & 2.060 & 1.165 & 26.797 \\
\hline Standardized $U R$ & -0.000 & 1.000 & -2.357 & 10.083 \\
\hline Subcontractor $(S U B)$ & 0.071 & 0.256 & 0.000 & 1.000 \\
\hline Observations & $1,353,017$ & & & \\
\hline
\end{tabular}


Table 2

The Effect of Economic Conditions and Labor Market Power on Wage And Hour VIOLATIONS

\begin{tabular}{|c|c|c|c|c|}
\hline & \multicolumn{4}{|c|}{ Panel A: Conditional Firm Fixed Effects Negative Binomial Regression } \\
\hline & $(1)$ & $(2)$ & (3) & (4) \\
\hline \multirow[t]{2}{*}{$U R$} & $1.161 * * *$ & $1.147 *$ & $1.152 * * *$ & $1.138 *$ \\
\hline & $(0.0379)$ & $(0.0660)$ & $(0.0386)$ & $(0.0583)$ \\
\hline \multirow[t]{2}{*}{$H H I$} & $0.271 * * *$ & $0.525 * *$ & $0.233 * * *$ & $0.456 * *$ \\
\hline & $(0.0590)$ & $(0.117)$ & $(0.0531)$ & $(0.122)$ \\
\hline \multirow[t]{2}{*}{$\log (H-1 B s)$} & $1.435 * * *$ & $1.447 * * *$ & $1.341 * * *$ & $1.344 * * *$ \\
\hline & $(0.0498)$ & $(0.0403)$ & $(0.0440)$ & $(0.0474)$ \\
\hline Year & $\mathrm{N}$ & $\mathrm{Y}$ & $\mathrm{N}$ & $\mathrm{Y}$ \\
\hline Occ & $\mathrm{N}$ & $\mathrm{N}$ & $\mathrm{Y}$ & $\mathrm{Y}$ \\
\hline Firm & $\mathrm{Y}$ & $\mathrm{Y}$ & $\mathrm{Y}$ & $\mathrm{Y}$ \\
\hline Number of Groups & 1218 & 1218 & 1218 & 1218 \\
\hline \multirow[t]{3}{*}{$\mathrm{N}$} & 25,673 & 25,673 & 25,673 & 25,673 \\
\hline & \multicolumn{4}{|c|}{ Panel B: Between Firm Random Effects Negative Binomial Regression } \\
\hline & $(1)$ & $(2)$ & $(3)$ & (4) \\
\hline \multirow[t]{2}{*}{$U R$} & $1.189 * * *$ & $1.166 * *$ & $1.187 * * *$ & $1.166^{*}$ \\
\hline & $(0.0413)$ & $(0.0689)$ & $(0.0312)$ & $(0.0752)$ \\
\hline \multirow[t]{2}{*}{$H H I$} & $0.329 * * *$ & $0.581 * *$ & $0.262 * * *$ & $0.493 * * *$ \\
\hline & $(0.0671)$ & $(0.103)$ & $(0.0537)$ & $(0.0976)$ \\
\hline \multirow[t]{2}{*}{$\log (H-1 B s)$} & $1.813 * * *$ & $1.836 * * *$ & $1.631 * * *$ & $1.645 * * *$ \\
\hline & $(0.0728)$ & $(0.0688)$ & $(0.0578)$ & $(0.0737)$ \\
\hline Year & $\mathrm{N}$ & $\mathrm{Y}$ & $\mathrm{N}$ & $\mathrm{Y}$ \\
\hline Occ & $\mathrm{N}$ & $\mathrm{N}$ & Y & $\mathrm{Y}$ \\
\hline Commuting Zone & $\mathrm{Y}$ & $\mathrm{Y}$ & $\mathrm{Y}$ & Y \\
\hline Number of Groups & 453,471 & 453,471 & 453,471 & 453,471 \\
\hline $\mathrm{N}$ & $1,351,775$ & $1,351,775$ & $1,351,775$ & $1,351,775$ \\
\hline
\end{tabular}

NOTE. $U R=$ Unemployment Rate. These regressions use STATA's $x$ tnbreg command. The top panel has conditional firm fixed effects, the bottom panel removes firm fixed effects and uses random effects. The dependent variable is the count of violations within a firm, year, commuting zone, and occupation. Exponentiated parameter estimates are reported, with bootstrapped standard errors of the coefficient in parentheses below each estimate. The coefficients are exponentiated and reflect the change in violations for a one standard deviation above average increase in the unemployment rate and a move from a competitive market to a monopsony. $* \mathrm{P}<.10 ; * * \mathrm{P}<.05 ; * * * \mathrm{P}<.01$. Statistical significance on a two-tailed test of the null hypothesis that an individual predictor has no effect. 
Table 3

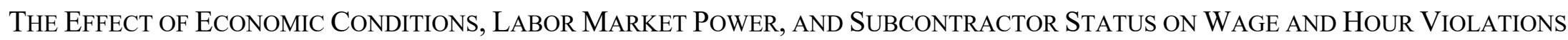

\begin{tabular}{lcccccccc}
\hline & $(1)$ & $(2)$ & $(3)$ & $(4)$ & $(5)$ & $(6)$ & $(7)$ & $(8)$ \\
\hline$U R$ & $1.246^{* * *}$ & $1.342^{* * *}$ & $1.112^{* *}$ & $1.174 * * *$ & $1.125^{* * *}$ & $1.367^{* * *}$ & 1.036 & $1.195^{*}$ \\
& $(0.0693)$ & $(0.144)$ & $(0.0473)$ & $(0.0614)$ & $(0.0467)$ & $(0.107)$ & $(0.125)$ & $(0.123)$ \\
$H H I$ & $0.496^{* * *}$ & 0.946 & $0.294 * * *$ & 1.761 & $0.295^{* * *}$ & $0.568^{* *}$ & $6.507^{* * *}$ & 1.068 \\
& $(0.135)$ & $(0.254)$ & $(0.0861)$ & $(0.697)$ & $(0.107)$ & $(0.148)$ & $(2.387)$ & $(0.366)$ \\
$S U B$ & $33.33^{* * *}$ & $59.23^{* * *}$ & $18.49 * * *$ & $17.35^{* * *}$ & $11.57 * * *$ & $31.89^{* * *}$ & $21.12^{* * *}$ & $15.26^{* * *}$ \\
& $(6.697)$ & $(15.57)$ & $(2.342)$ & $(3.253)$ & $(1.304)$ & $(5.266)$ & $(3.293)$ & $(1.673)$ \\
$S U B \times H H I$ & $0.0110^{* * *}$ & $0.00996^{* * *}$ & $0.0393^{* * *}$ & $0.0290^{* * *}$ & $0.0894^{* * *}$ & $0.0331^{* * *}$ & $0.0440^{* * *}$ & $0.0898^{* * *}$ \\
& $(0.00766)$ & $(0.00821)$ & $(0.0254)$ & $(0.0196)$ & $(0.0508)$ & $(0.0245)$ & $(0.0280)$ & $(0.0511)$ \\
$S U B \times U R$ & 1.195 & 0.992 & $1.318^{* * *}$ & $1.291^{* *}$ & $1.366^{* * *}$ & 1.106 & 1.181 & $1.243^{* * *}$ \\
& $(0.156)$ & $(0.135)$ & $(0.115)$ & $(0.156)$ & $(0.110)$ & $(0.102)$ & $(0.126)$ & $(0.0957)$ \\
$\log (H-1 B s)$ & $3.856^{* * *}$ & $3.567 * * *$ & $3.063 * * *$ & $3.803 * * *$ & $2.983 * * *$ & $2.749^{* * *}$ & $3.618^{* * *}$ & $2.818^{* * *}$ \\
& $(0.181)$ & $(0.153)$ & $(0.118)$ & $(0.146)$ & $(0.102)$ & $(0.105)$ & $(0.130)$ & $(0.0924)$ \\
Year & $\mathrm{N}$ & $\mathrm{Y}$ & $\mathrm{N}$ & $\mathrm{N}$ & $\mathrm{N}$ & $\mathrm{Y}$ & $\mathrm{Y}$ & $\mathrm{Y}$ \\
Occupation & $\mathrm{N}$ & $\mathrm{N}$ & $\mathrm{Y}$ & $\mathrm{N}$ & $\mathrm{Y}$ & $\mathrm{Y}$ & $\mathrm{N}$ & $\mathrm{Y}$ \\
Commuting Zone & $\mathrm{N}$ & $\mathrm{N}$ & $\mathrm{N}$ & $\mathrm{Y}$ & $\mathrm{Y}$ & $\mathrm{N}$ & $\mathrm{Y}$ & $\mathrm{Y}$ \\
$\mathrm{N}$ & $1,351,786$ & $1,351,786$ & $1,351,786$ & $1,351,786$ & $1,351,786$ & $1,351,786$ & $1,351,786$ & $1,351,786$ \\
\hline
\end{tabular}

Note. $U R=$ Unemployment Rate. $S U B=$ subcontractor. This is an unconditional negative binomial regression. The dependent variable is the count of violations within a firm, year, commuting zone, and occupation. Exponentiated parameter estimates are reported, with bootstrapped standard errors of the coefficient in parentheses below each estimate. The coefficients are exponentiated and reflect the change in the rate of violations for a one standard deviation above average increase in the unemployment rate and a move from a competitive market to a monopsony.

$* \mathrm{P}<.10 ; * * \mathrm{P}<.05 ; * * * \mathrm{P}<.01$. Statistical significance on a two-tailed test of the null hypothesis that an individual predictor has no effect. 


\section{Table 4}

The EfFect of Economic Conditions and Labor Market Power on Log(1+ Back Wages

PER 1000 H-1BS)

\begin{tabular}{|c|c|c|c|c|}
\hline & \multicolumn{4}{|c|}{ Panel A: Within Firm Ordinary Least Squares } \\
\hline & (1) & (2) & (3) & (4) \\
\hline \multirow[t]{2}{*}{$U R$} & 0.00113 & $0.00615 * *$ & 0.00126 & $0.00625^{* *}$ \\
\hline & $(0.00131)$ & $(0.00300)$ & $(0.00131)$ & $(0.00300)$ \\
\hline \multirow[t]{2}{*}{$H H I$} & $-0.0483 * * *$ & $-0.0249 * * *$ & $-0.0434 * * *$ & $-0.0215^{* *}$ \\
\hline & $(0.00837)$ & $(0.00836)$ & $(0.00881)$ & $(0.00880)$ \\
\hline \multirow[t]{2}{*}{$\log (H-1 B s)$} & $0.0173 * * *$ & $0.0166^{* * *}$ & $0.0216 * * *$ & $0.0211 * * *$ \\
\hline & $(0.00332)$ & $(0.00332)$ & $(0.00327)$ & $(0.00328)$ \\
\hline Year & $\mathrm{N}$ & $\mathrm{Y}$ & $\mathrm{N}$ & $\mathrm{Y}$ \\
\hline Occ & $\mathrm{N}$ & $\mathrm{N}$ & Y & Y \\
\hline Firm & Y & $\mathrm{Y}$ & Y & $\mathrm{Y}$ \\
\hline $\mathrm{R}^{2}$ & 0.34 & 0.34 & 0.34 & 0.34 \\
\hline Number of Groups & 419,731 & 419,731 & 419,731 & 419,731 \\
\hline \multirow[t]{3}{*}{$\mathrm{N}$} & $1,237,770$ & $1,237,770$ & $1,237,770$ & $1,237,770$ \\
\hline & \multicolumn{4}{|c|}{ Panel B: Between Firm Ordinary Least Squares } \\
\hline & (1) & (2) & (3) & (4) \\
\hline \multirow[t]{2}{*}{$U R$} & $0.00645^{* * *}$ & $0.00737 * * *$ & $0.00654 * * *$ & $0.00786^{* * *}$ \\
\hline & $(0.000749)$ & $(0.00122)$ & $(0.000749)$ & $(0.00123)$ \\
\hline \multirow[t]{2}{*}{$H H I$} & $-0.0387 * * *$ & $-0.0238 * * *$ & $-0.0382 * * *$ & $-0.0224 * * *$ \\
\hline & $(0.00342)$ & $(0.00337)$ & $(0.00364)$ & $(0.00359)$ \\
\hline \multirow[t]{2}{*}{$\log (H-1 B s)$} & $0.0890^{* * *}$ & $0.0898^{* * *}$ & $0.0888 * * *$ & $0.0897 * * *$ \\
\hline & $(0.00221)$ & $(0.00222)$ & $(0.00219)$ & $(0.00220)$ \\
\hline Year & $\mathrm{N}$ & $\mathrm{Y}$ & $\mathrm{N}$ & Y \\
\hline Occ & $\mathrm{N}$ & $\mathrm{N}$ & $\mathrm{Y}$ & $\mathrm{Y}$ \\
\hline Commuting Zone & Y & Y & Y & $\mathrm{Y}$ \\
\hline $\mathrm{R}^{2}$ & 0.01 & 0.01 & 0.01 & 0.01 \\
\hline $\mathrm{N}$ & $1,237,779$ & $1,237,779$ & $1,237,779$ & $1,237,779$ \\
\hline
\end{tabular}

NOTE. $U R=$ Unemployment Rate. This is an ordinary least squares regression. The dependent variable is $\log \left(1+1000\left(\frac{\text { Back Wages }_{f, o, c, t}}{H 1 B s_{f, o, c z, t}}\right)\right)$. Parameter estimates are reported, with robust standard errors in parentheses below each estimate. The coefficients reflect the average change in the log of back wages for a one standard deviation above average increase in the unemployment rate and a move from a competitive market to a monopsony.

$* \mathrm{P}<.10 ; * * \mathrm{P}<.05 ; * * * \mathrm{P}<.01$. 
Table 5

The EfFect of Economic Conditions, Labor Market Power, And Subcontractor on Log(1+ Back Wages Per 1000 H-1Bs)

\begin{tabular}{|c|c|c|c|c|c|c|c|c|}
\hline & $(1)$ & $(2)$ & (3) & (4) & $(5)$ & $(6)$ & $(7)$ & $(8)$ \\
\hline$U R$ & $\begin{array}{c}0.00397 * * * \\
(0.000637)\end{array}$ & $\begin{array}{c}0.00695 * * * \\
(0.00119)\end{array}$ & $\begin{array}{c}0.00399 * * * \\
(0.000638)\end{array}$ & $\begin{array}{c}0.00276 * * * \\
(0.000736)\end{array}$ & $\begin{array}{c}0.00268 * * * \\
(0.000736)\end{array}$ & $\begin{array}{c}0.00729 * * * \\
(0.00119)\end{array}$ & $\begin{array}{c}0.00227 \\
(0.00203)\end{array}$ & $\begin{array}{c}0.00243 \\
(0.00203)\end{array}$ \\
\hline$H H I$ & $\begin{array}{c}-0.0272 * * * \\
(0.00277)\end{array}$ & $\begin{array}{c}-0.0105 * * * \\
(0.00277)\end{array}$ & $\begin{array}{c}-0.0258 * * * \\
(0.00297)\end{array}$ & $\begin{array}{c}-0.0208 * * * \\
(0.00411)\end{array}$ & $\begin{array}{c}-0.0271 * * * \\
(0.00449)\end{array}$ & $\begin{array}{c}-0.00828 * * * \\
(0.00297)\end{array}$ & $\begin{array}{l}0.00881 * * \\
(0.00419)\end{array}$ & $\begin{array}{c}0.00229 \\
(0.00456)\end{array}$ \\
\hline$S U B$ & $\begin{array}{l}0.203 * * * \\
(0.00918)\end{array}$ & $\begin{array}{l}0.211 * * * \\
(0.00924)\end{array}$ & $\begin{array}{l}0.202 * * * \\
(0.00923)\end{array}$ & $\begin{array}{l}0.194 * * * \\
(0.00924)\end{array}$ & $\begin{array}{l}0.193 * * * \\
(0.00928)\end{array}$ & $\begin{array}{l}0.210^{* * *} \\
(0.00929)\end{array}$ & $\begin{array}{l}0.202 * * * \\
(0.00930)\end{array}$ & $\begin{array}{l}0.201 * * * \\
(0.00933)\end{array}$ \\
\hline$S U B \times H H I$ & $\begin{array}{c}-0.261 * * * \\
(0.0300)\end{array}$ & $\begin{array}{c}-0.256^{* * *} \\
(0.0300)\end{array}$ & $\begin{array}{c}-0.263 * * * \\
(0.0300)\end{array}$ & $\begin{array}{c}-0.251 * * * \\
(0.0308)\end{array}$ & $\begin{array}{c}-0.250 * * * \\
(0.0308)\end{array}$ & $\begin{array}{c}-0.259 * * * \\
(0.0300)\end{array}$ & $\begin{array}{c}-0.248 * * * \\
(0.0307)\end{array}$ & $\begin{array}{c}-0.248 * * * \\
(0.0307)\end{array}$ \\
\hline$S U B \times U R$ & $\begin{array}{c}0.0277 * * * \\
(0.00670)\end{array}$ & $\begin{array}{c}0.0229 * * * \\
(0.00675)\end{array}$ & $\begin{array}{c}0.0278 * * * \\
(0.00670)\end{array}$ & $\begin{array}{c}0.0251 * * * \\
(0.00671)\end{array}$ & $\begin{array}{c}0.0251 * * * \\
(0.00671)\end{array}$ & $\begin{array}{c}0.0229 * * * \\
(0.00675)\end{array}$ & $\begin{array}{c}0.0199 * * * \\
(0.00677)\end{array}$ & $\begin{array}{c}0.0198 * * * \\
(0.00677)\end{array}$ \\
\hline $\log (H-1 B s)$ & $\begin{array}{c}0.0700 * * * \\
(0.00225)\end{array}$ & $\begin{array}{c}0.0699 * * * \\
(0.00225)\end{array}$ & $\begin{array}{c}0.0708 * * * \\
(0.00222)\end{array}$ & $\begin{array}{c}0.0680^{* * * *} \\
(0.00224)\end{array}$ & $\begin{array}{c}0.0690^{* * * *} \\
(0.00222)\end{array}$ & $\begin{array}{c}0.0707 * * * \\
(0.00222)\end{array}$ & $\begin{array}{c}0.0678 * * * \\
(0.00225)\end{array}$ & $\begin{array}{c}0.0689 * * * \\
(0.00222)\end{array}$ \\
\hline Year & $\mathrm{N}$ & $\mathrm{Y}$ & $\mathrm{N}$ & $\mathrm{N}$ & $\mathrm{N}$ & $\mathrm{Y}$ & $\mathrm{Y}$ & $\mathrm{Y}$ \\
\hline Occupation & $\mathrm{N}$ & $\mathrm{N}$ & Y & $\mathrm{N}$ & $\mathrm{Y}$ & Y & $\mathrm{N}$ & $\mathrm{Y}$ \\
\hline Commuting Zone & $\mathrm{N}$ & $\mathrm{N}$ & $\mathrm{N}$ & $\mathrm{Y}$ & $\mathrm{Y}$ & $\mathrm{N}$ & Y & $\mathrm{Y}$ \\
\hline $\mathrm{R}^{2}$ & 0.01 & 0.01 & 0.01 & 0.01 & 0.01 & 0.01 & 0.01 & 0.01 \\
\hline $\mathrm{N}$ & $1,237,779$ & $1,237,779$ & $1,237,779$ & $1,237,779$ & $1,237,779$ & $1,237,779$ & $1,237,779$ & $1,237,779$ \\
\hline
\end{tabular}

NOTE. $U R=$ Unemployment Rate. $S U B=$ Subcontractor. This is an ordinary least squares regression. The dependent variable is

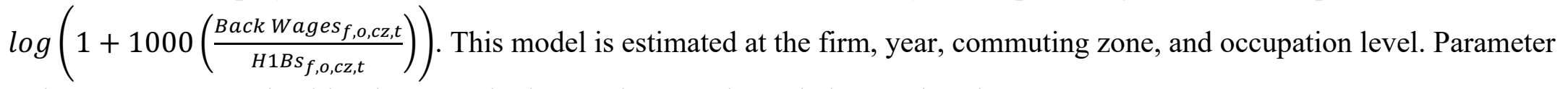
estimates are reported, with robust standard errors in parentheses below each estimate.

$* \mathrm{P}<.10 ; * * \mathrm{P}<.05 ; * * * \mathrm{P}<.01$. Statistical significance on a two-tailed test of the null hypothesis that an individual predictor has no effect. 


\section{Table 6}

Marginal Effects: Change in Probability at Mean

\begin{tabular}{ccccc}
\hline \multirow{2}{*}{} & \multicolumn{2}{c}{ Panel A: Change in Probability a Firm Ever Exits or Violates } \\
\cline { 2 - 5 } & \multicolumn{2}{c}{ Unweighted } & \multicolumn{2}{c}{ Population Weighted } \\
\cline { 2 - 5 } & Ever Exits & Ever Violates & Ever Exits & Ever Violates \\
\hline$\widehat{U R}$ & $0.0976^{* * *}$ & $0.00221 * * *$ & $0.00176^{* * *}$ & $0.0255^{* * *}$ \\
& $(0.00432)$ & $(0.000645)$ & $(0.000471)$ & $(0.000349)$ \\
$\mathrm{N}$ & $-0.438^{* * *}$ & $-0.0135 * * *$ & $-0.446 * * *$ & $-0.124 * * *$ \\
& $(0.0183)$ & $(0.00321)$ & $(0.00229)$ & $(0.00122)$ \\
& 38,198 & 38,198 & $3,246,335$ & $3,246,335$ \\
\hline$U R_{\mathrm{t}-1}$ & $0.00787 * * *$ & $0.000937 * * *$ & $0.000378 * * *$ & $0.00165 * * *$ \\
& $(0.00134)$ & $(0.000159)$ & $(0.000112)$ & $(0.000241)$ \\
$H H I_{\mathrm{t}-1}$ & $-0.0321 * * *$ & $-0.00322 * * *$ & $-0.00329 * * *$ & $-0.0240 * * *$ \\
& $(0.00553)$ & $(0.000684)$ & $(0.000433)$ & $(0.000899)$ \\
$\mathrm{N}$ & 225,304 & 225,304 & $2,601,607$ & $2,601,607$
\end{tabular}

Note: Standard errors are robust. This Table reports the marginal effect of a one standard deviation increase in the average unemployment rate $(U R)$ and the effect of a firm's workers being located in a monopsony $(H H I=1)$ compared to a competitive market on the probability of firm exit from the panel and firm violations at mean values of $U R$ and $H H I$. Panel A estimates the marginal effect on the probability that a firm ever exits or has a violation using average $U R$ and $H H I$ a firm faces for the duration of the study and includes a control for the log of the number of $\mathrm{H}-1 \mathrm{Bs}$ in a firm. Panel B estimates the probability that a firm exits or has a violation in a given year with prior year's $H H I$ and $U R$ as predictors, and also includes controls for H-1B population and year indicator variables.

$* \mathrm{P}<.10 ; * * \mathrm{P}<.05 ; * * * \mathrm{P}<.01$. Statistical significance on a two-tailed test of the null hypothesis that an individual predictor has no effect. 
Table 7

Marginal Effects: Probabilities at CRitical VAlues

\begin{tabular}{rcccc}
\hline & \multicolumn{3}{c}{ Panel A: Probability a Firm Ever Exits or Violates } \\
\cline { 2 - 5 } & \multicolumn{2}{c}{ Unweighted } & \multicolumn{2}{c}{ Population Weighted } \\
\cline { 2 - 5 } & Ever Exits & Ever Violates & Ever Exits & Ever Violates \\
\hline$\widehat{U R}=0, \widehat{H H I}=0$ & 0.710 & 0.0291 & 0.351 & 0.155 \\
$\widehat{U R}=1, \widehat{H H I}=0$ & 0.785 & 0.0342 & 0.353 & 0.186 \\
$\widehat{U R}=0, \widehat{H H I}=1$ & 0.300 & 0.00995 & 0.0680 & 0.0523 \\
$\widehat{U R}=1, \widehat{H H I}=1$ & 0.390 & 0.0120 & 0.0686 & 0.0669 \\
$\mathrm{~N}$ & 38,198 & 38,198 & $3,246,335$ & $3,246,335$ \\
\hline & Panel B: Probability a Firm Ever Exits or Violates at $\mathrm{t}=0$ \\
\hline$U R_{\mathrm{t}-1}=0, H H I_{\mathrm{t}-1}=0$ & 0.221 & 0.0109 & 0.0859 & 0.0459 \\
$U R_{\mathrm{t}-1}=1, H H I_{\mathrm{t}-1}=0$ & 0.229 & 0.0132 & 0.0879 & 0.0502 \\
$U R_{\mathrm{t}-1}=0, H H I_{\mathrm{t}-1}=1$ & 0.190 & 0.00557 & 0.0607 & 0.0158 \\
$U R_{\mathrm{t}-1}=, H H I_{\mathrm{t}-1}=1$ & 0.198 & 0.00681 & 0.0623 & 0.0176 \\
$\mathrm{~N}$ & 225,304 & 225,304 & $2,601,607$ & $2,601,607$ \\
\hline
\end{tabular}




\section{Appendix A - Tables and Figures}

Table A.1

The EFfect of ECONOMic CONDitions AND LABOR MARKet Power on Log( 1 + Violations PER $1000 \mathrm{H}-1 \mathrm{BS})$

\begin{tabular}{|c|c|c|c|c|}
\hline & \multicolumn{4}{|c|}{ Panel A: Within Firm Ordinary Least Squares } \\
\hline & (1) & (2) & (3) & (4) \\
\hline \multirow[t]{2}{*}{$U R$} & $0.00485 * * *$ & $0.00631 * * *$ & $0.00488 * * *$ & $0.00631 * * *$ \\
\hline & $(0.000589)$ & $(0.00138)$ & $(0.000589)$ & $(0.00138)$ \\
\hline \multirow[t]{2}{*}{$H H I$} & $-0.0245 * * *$ & $-0.0133 * * *$ & $-0.0237 * * *$ & $-0.0132 * * *$ \\
\hline & $(0.00341)$ & $(0.00340)$ & $(0.00355)$ & $(0.00354)$ \\
\hline \multirow[t]{2}{*}{$\log (H-1 B s)$} & $0.00618 * * *$ & $0.00597 * * *$ & $0.00638 * * *$ & $0.00626 * * *$ \\
\hline & $(0.00137)$ & $(0.00137)$ & $(0.00136)$ & $(0.00136)$ \\
\hline Year & $\mathrm{N}$ & $\mathrm{Y}$ & $\mathrm{N}$ & $\mathrm{Y}$ \\
\hline Occ & $\mathrm{N}$ & $\mathrm{N}$ & Y & Y \\
\hline Firm & Y & Y & $\mathrm{Y}$ & Y \\
\hline $\mathrm{R}^{2}$ & 0.44 & 0.44 & 0.44 & 0.44 \\
\hline Number of Groups & 419,731 & 419,731 & 419,731 & 419,731 \\
\hline \multirow[t]{3}{*}{$\mathrm{N}$} & $1,237,770$ & $1,237,770$ & $1,237,770$ & $1,237,770$ \\
\hline & \multicolumn{4}{|c|}{ Panel B: Between Firm Ordinary Least Squares } \\
\hline & $(1)$ & $(2)$ & $(3)$ & $(4)$ \\
\hline \multirow[t]{2}{*}{$U R$} & $0.00572 * * *$ & $0.00537 * * *$ & $0.00586 * * *$ & $0.00578 * * *$ \\
\hline & $(0.000382)$ & $(0.000616)$ & $(0.000383)$ & $(0.000619)$ \\
\hline \multirow{2}{*}{$H H I$} & $-0.0188 * * *$ & $-0.0113 * * *$ & $-0.0195 * * *$ & $-0.0114 * * *$ \\
\hline & $(0.00147)$ & $(0.00144)$ & $(0.00156)$ & $(0.00153)$ \\
\hline \multirow[t]{2}{*}{$\log (H-1 B s)$} & $0.0453 * * *$ & $0.0457 * * *$ & $0.0434 * * *$ & $0.0439 * * *$ \\
\hline & (0.000999) & $(0.00100)$ & $(0.000973)$ & $(0.000978)$ \\
\hline Year & $\mathrm{N}$ & $\mathrm{Y}$ & $\mathrm{N}$ & $\mathrm{Y}$ \\
\hline Occ & $\mathrm{N}$ & $\mathrm{N}$ & $\mathrm{Y}$ & $\mathrm{Y}$ \\
\hline Commuting Zone & $\mathrm{Y}$ & $\mathrm{Y}$ & $\mathrm{Y}$ & $\mathrm{Y}$ \\
\hline $\mathrm{R}^{2}$ & 0.01 & 0.01 & 0.01 & 0.01 \\
\hline $\mathrm{N}$ & $1,237,779$ & $1,237,779$ & $1,237,779$ & $1,237,779$ \\
\hline
\end{tabular}

NOTE. $U R=$ Unemployment Rate. This is an ordinary least squares regression. The dependent variable is $\log \left(1+1000\left(\frac{\text { Violations }_{f, o, c z, t}}{H 1 B s_{f, o, c z, t}}\right)\right)$ within a firm, year, commuting zone, and occupation. Parameter estimates are reported, with robust standard errors in parentheses below each estimate. The coefficients reflect the change in the dependent variable for a one standard deviation above average increase in the unemployment rate and a move from a competitive market to a monopsony.

$* \mathrm{P}<.10 ; * * \mathrm{P}<.05 ; * * * \mathrm{P}<.01$. 
Table A.2

The Effect of Economic Conditions, Labor Market Power, and Subcontractor on Log(1 + Violations Per 1000 H-1Bs)

\begin{tabular}{|c|c|c|c|c|c|c|c|c|}
\hline & $(1)$ & (2) & (3) & (4) & $(5)$ & (6) & (7) & $(8)$ \\
\hline \multirow[t]{2}{*}{$U R$} & $0.00286 * * *$ & $0.00370 * * *$ & $0.00298 * * *$ & $0.00244 * * *$ & $0.00245 * * *$ & $0.00402 * * *$ & 0.00149 & 0.00152 \\
\hline & $(0.000316)$ & $(0.000589)$ & $(0.000317)$ & $(0.000358)$ & $(0.000359)$ & $(0.000591)$ & $(0.000985)$ & $(0.000985)$ \\
\hline \multirow[t]{2}{*}{$H H I$} & $-0.0103 * * *$ & -0.00201 & $-0.0106 * * *$ & $-0.00845 * * *$ & $-0.0142 * * *$ & -0.00174 & $0.00633 * * *$ & 0.000717 \\
\hline & $(0.00126)$ & $(0.00125)$ & $(0.00134)$ & $(0.00183)$ & $(0.00201)$ & $(0.00134)$ & $(0.00185)$ & $(0.00202)$ \\
\hline \multirow[t]{2}{*}{$S U B$} & $0.111 * * *$ & $0.115 * * *$ & $0.109 * * *$ & $0.106 * * *$ & $0.105 * * *$ & $0.113 * * *$ & $0.110 * * *$ & $0.108 * * *$ \\
\hline & $(0.00414)$ & $(0.00416)$ & $(0.00415)$ & $(0.00417)$ & $(0.00418)$ & $(0.00417)$ & $(0.00419)$ & $(0.00420)$ \\
\hline \multirow[t]{2}{*}{$S U B \times H H I$} & $-0.168 * * *$ & $-0.166 * * *$ & $-0.167 * * *$ & $-0.162 * * *$ & $-0.160 * * *$ & $-0.165 * * *$ & $-0.161 * * *$ & $-0.159 * * *$ \\
\hline & $(0.0121)$ & $(0.0120)$ & $(0.0121)$ & $(0.0124)$ & $(0.0124)$ & $(0.0120)$ & $(0.0124)$ & $(0.0124)$ \\
\hline \multirow[t]{2}{*}{$S U B \times U R$} & $0.0370 * * *$ & $0.0349 * * *$ & $0.0369 * * *$ & $0.0353 * * *$ & $0.0352 * * *$ & $0.0348 * * *$ & $0.0330 * * *$ & $0.0329 * * *$ \\
\hline & $(0.00350)$ & $(0.00352)$ & $(0.00350)$ & $(0.00350)$ & $(0.00350)$ & $(0.00352)$ & $(0.00352)$ & $(0.00352)$ \\
\hline \multirow[t]{2}{*}{$\log (H-1 B s)$} & $0.0354 * * *$ & $0.0354 * * *$ & $0.0342 * * *$ & $0.0345 * * *$ & $0.0335 * * *$ & $0.0343 * * *$ & $0.0344 * * *$ & $0.0335 * * *$ \\
\hline & $(0.00101)$ & $(0.00101)$ & $(0.000983)$ & $(0.00101)$ & $(0.000986)$ & $(0.000984)$ & $(0.00101)$ & $(0.000987)$ \\
\hline Year & $\mathrm{N}$ & $\mathrm{Y}$ & $\mathrm{N}$ & $\mathrm{N}$ & $\mathrm{N}$ & $\mathrm{Y}$ & $\mathrm{Y}$ & $\mathrm{Y}$ \\
\hline Occupation & $\mathrm{N}$ & $\mathrm{N}$ & Y & $\mathrm{N}$ & $\mathrm{Y}$ & Y & $\mathrm{N}$ & $\mathrm{Y}$ \\
\hline Commuting Zone & $\mathrm{N}$ & $\mathrm{N}$ & $\mathrm{N}$ & $\mathrm{Y}$ & $\mathrm{Y}$ & $\mathrm{N}$ & $\mathrm{Y}$ & $\mathrm{Y}$ \\
\hline $\mathrm{R}^{2}$ & 0.01 & 0.01 & 0.01 & 0.01 & 0.01 & 0.01 & 0.02 & 0.02 \\
\hline $\mathrm{N}$ & $1,237,779$ & $1,237,779$ & $1,237,779$ & $1,237,750$ & $1,237,750$ & $1,237,779$ & $1,237,750$ & $1,237,750$ \\
\hline
\end{tabular}

NOTE. $U R=$ Unemployment Rate. $S U B=$ Subcontractor. This is an ordinary least squares regression. This model is estimated at the firm, year, commuting zone, and occupation level. The dependent variable is $\log \left(1+1000\left(\frac{\text { Violations }_{f, o, c z, t}}{H 1 B s}\right)\right)$ within a firm, year, occupation, and commuting zone. Parameter estimates are reported, with robust standard errors in parentheses below each estimate. $* \mathrm{P}<.10 ; * * \mathrm{P}<.05 ; * * * \mathrm{P}<.01$. Statistical significance on a two-tailed test of the null hypothesis that an individual predictor has no effect. 
Table A.3

WEIGHTED OLS REGRESSION: THE EFFECT OF ECONOMIC CONDITIONS AND LABOR MARKET POWER ON LOG(1 + Violations PER 1000 H-1Bs)

\begin{tabular}{|c|c|c|c|c|}
\hline & \multicolumn{4}{|c|}{ Panel A: Within Firm Ordinary Least Squares } \\
\hline & $(1)$ & $(2)$ & $(3)$ & $(4)$ \\
\hline \multirow[t]{2}{*}{$U R$} & $0.0106 * * *$ & $0.0112 * * *$ & $0.0105 * * *$ & $0.0112 * * *$ \\
\hline & $(0.000436)$ & $(0.00105)$ & $(0.000437)$ & $(0.00105)$ \\
\hline \multirow[t]{2}{*}{$H H I$} & $-0.106^{* * *}$ & $-0.0384 * * *$ & $-0.111 * * *$ & $-0.0470 * * *$ \\
\hline & $(0.00244)$ & $(0.00241)$ & $(0.00252)$ & $(0.00248)$ \\
\hline \multirow[t]{2}{*}{$\log (H-1 B s)$} & $0.0215 * * *$ & $0.0213 * * *$ & $0.0198 * * *$ & $0.0196 * * *$ \\
\hline & $(0.000509)$ & $(0.000511)$ & $(0.000517)$ & $(0.000520)$ \\
\hline Year & $\mathrm{N}$ & $\mathrm{Y}$ & $\mathrm{N}$ & $\mathrm{Y}$ \\
\hline Occ & $\mathrm{N}$ & $\mathrm{N}$ & $\mathrm{Y}$ & $\mathrm{Y}$ \\
\hline Firm & Y & Y & Y & $\mathrm{Y}$ \\
\hline $\mathrm{R}^{2}$ & 0.47 & 0.47 & 0.47 & 0.47 \\
\hline Number of Groups & 419,731 & 419,731 & 419,731 & 419,731 \\
\hline \multirow[t]{2}{*}{$\mathrm{N}$} & $4,746,618$ & $4,746,618$ & $4,746,618$ & $4,746,618$ \\
\hline & \multicolumn{4}{|c|}{ Panel B: Between Firm Ordinary Least Squares } \\
\hline \multirow[t]{2}{*}{$U R$} & $0.0174 * * *$ & $0.0187 * * *$ & $0.0187 * * *$ & $0.0198 * * *$ \\
\hline & $(0.000406)$ & $(0.000710)$ & $(0.000406)$ & $(0.000709)$ \\
\hline \multirow[t]{2}{*}{$H H I$} & $-0.119 * * *$ & $-0.0669 * * *$ & $-0.109 * * *$ & $-0.0492 * * *$ \\
\hline & $(0.00151)$ & $(0.00147)$ & $(0.00158)$ & $(0.00153)$ \\
\hline \multirow[t]{2}{*}{$\log (H-1 B s)$} & $0.0662 * * *$ & $0.0702 * * *$ & $0.0533 * * *$ & $0.0568 * * *$ \\
\hline & $(0.000263)$ & $(0.000275)$ & $(0.000236)$ & $(0.000246)$ \\
\hline Year & $\mathrm{N}$ & $\mathrm{Y}$ & $\mathrm{N}$ & $\mathrm{Y}$ \\
\hline Occ & $\mathrm{N}$ & $\mathrm{N}$ & $\mathrm{Y}$ & $\mathrm{Y}$ \\
\hline Commuting Zone & $\mathrm{Y}$ & $\mathrm{Y}$ & $\mathrm{Y}$ & $\mathrm{Y}$ \\
\hline $\mathrm{R}^{2}$ & 0.01 & 0.03 & 0.02 & 0.03 \\
\hline $\mathrm{N}$ & $4,746,628$ & $4,746,628$ & $4,746,628$ & $4,746,628$ \\
\hline
\end{tabular}

Note. $U R=$ Unemployment Rate. This is a weighted ordinary least squared regression. The dependent variable is $\log \left(1+1000 *\left(\frac{\text { violations }_{f, o, c z, t}}{H 1 B s_{f, o, c z, t}}\right)\right)$ within a firm, year, commuting zone, and occupation. Parameter estimates are reported, with standard errors in parentheses below each estimate. The coefficients reflect the change in the log of the count of violations for a one standard deviation above average increase in the unemployment rate and a move from a competitive market to a monopsony.

$* \mathrm{P}<.10 ; * * \mathrm{P}<.05 ; * * * \mathrm{P}<.01$. Statistical significance on a two-tailed test of the null hypothesis that an individual predictor has no effect. 


\section{Table A.4}

WEIGHTED OLS REGRESSION: THE EFFECT OF ECONOMIC CONDITIONS AND LABOR MARKET POWER ON LOG(1+BACK WAges PER 1000 H-1Bs)

\begin{tabular}{|c|c|c|c|c|}
\hline & \multicolumn{4}{|c|}{ Panel A: Within Firm Weighted Ordinary Least Squares } \\
\hline & $(1)$ & (2) & (3) & (4) \\
\hline \multirow[t]{2}{*}{$U R$} & $-0.0179 * * *$ & $0.0110 * * *$ & $-0.0173 * * *$ & $0.0114 * * *$ \\
\hline & $(0.000990)$ & $(0.00231)$ & $(0.000991)$ & $(0.00231)$ \\
\hline \multirow[t]{2}{*}{$H H I$} & $-0.165 * * *$ & $-0.0402 * * *$ & $-0.160 * * *$ & $-0.0424 * * *$ \\
\hline & $(0.00616)$ & $(0.00612)$ & $(0.00635)$ & $(0.00630)$ \\
\hline \multirow[t]{2}{*}{$\log (H-1 B s)$} & $0.0608^{* * *}$ & $0.0592 * * *$ & $0.0676 * * *$ & $0.0659 * * *$ \\
\hline & $(0.00124)$ & $(0.00124)$ & $(0.00123)$ & $(0.00123)$ \\
\hline Year & $\mathrm{N}$ & $\mathrm{Y}$ & $\mathrm{N}$ & $\mathrm{Y}$ \\
\hline Occ & $\mathrm{N}$ & $\mathrm{N}$ & Y & $\mathrm{Y}$ \\
\hline Firm & Y & Y & Y & $\mathrm{Y}$ \\
\hline $\mathrm{R}^{2}$ & 0.35 & 0.36 & 0.35 & 0.36 \\
\hline Number of Groups & 419,731 & 419,731 & 419,731 & 419,731 \\
\hline \multirow[t]{3}{*}{$\mathrm{N}$} & $4,746,618$ & $4,746,618$ & $4,746,618$ & $4,746,618$ \\
\hline & \multicolumn{4}{|c|}{ Panel B: Between Firm Weighted Ordinary Least Squares } \\
\hline & $(1)$ & $(2)$ & $(3)$ & (4) \\
\hline \multirow[t]{2}{*}{$U R$} & $0.00888 * * *$ & $0.0293 * * *$ & $0.0109 * * *$ & $0.0307 * * *$ \\
\hline & $(0.000786)$ & $(0.00137)$ & $(0.000786)$ & $(0.00138)$ \\
\hline \multirow[t]{2}{*}{$H H I$} & $-0.211 * * *$ & $-0.110 * * *$ & $-0.189 * * *$ & $-0.0753 * * *$ \\
\hline & $(0.00364)$ & $(0.00355)$ & $(0.00380)$ & $(0.00371)$ \\
\hline \multirow[t]{2}{*}{$\log (H-1 B s)$} & $0.138 * * *$ & $0.145 * * *$ & $0.122 * * *$ & $0.128 * * *$ \\
\hline & $(0.000595)$ & $(0.000616)$ & $(0.000566)$ & $(0.000581)$ \\
\hline Year & $\mathrm{N}$ & $\mathrm{Y}$ & $\mathrm{N}$ & $\mathrm{Y}$ \\
\hline Occ & $\mathrm{N}$ & $\mathrm{N}$ & $\mathrm{Y}$ & Y \\
\hline Commuting Zone & $\mathrm{Y}$ & $\mathrm{Y}$ & Y & Y \\
\hline $\mathrm{R}^{2}$ & 0.013 & 0.022 & 0.016 & 0.025 \\
\hline $\mathrm{N}$ & $4,746,628$ & $4,746,628$ & $4,746,628$ & $4,746,628$ \\
\hline
\end{tabular}

Note. $U R=$ Unemployment Rate. This is a weighted ordinary least squares regression. The dependent variable is $\log \left(1+1000\left(\frac{{\text { Back } \operatorname{Wages}_{f, o, c z, t}}_{H 1 B s_{f, o, c z, t}}}{H}\right)\right)$. Parameter estimates are reported, with robust standard errors in parentheses below each estimate. The coefficients reflect the average change in the dependent variable for a one standard deviation above average increase in the unemployment rate and a move from a competitive market to a monopsony.

$* \mathrm{P}<.10 ; * * \mathrm{P}<.05 ; * * * \mathrm{P}<.01$. 
Table A.5

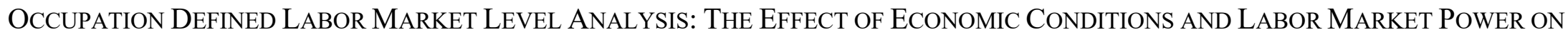
VIOLATIONS

\begin{tabular}{|c|c|c|c|c|c|c|c|c|}
\hline & $(1)$ & $(2)$ & (3) & (4) & $(5)$ & $(6)$ & $(7)$ & $(8)$ \\
\hline \multirow{2}{*}{$U R$} & $0.891^{*}$ & $0.845 * * *$ & 0.950 & $1.186^{* * *}$ & $1.133 * * *$ & $0.866^{* * *}$ & $1.439 * * *$ & $1.312 * * *$ \\
\hline & $(0.0527)$ & $(0.0500)$ & $(0.0372)$ & $(0.0233)$ & $(0.0201)$ & $(0.0415)$ & $(0.134)$ & $(0.109)$ \\
\hline \multirow[t]{2}{*}{$H H I$} & $0.246 * * *$ & $0.246^{* * *}$ & $0.186^{* * *}$ & $0.264 * * *$ & $0.332 * * *$ & $0.191 * * *$ & $0.354 * * *$ & $0.441 * * *$ \\
\hline & $(0.0762)$ & $(0.0569)$ & $(0.0414)$ & $(0.0722)$ & $(0.0796)$ & $(0.0377)$ & $(0.0927)$ & $(0.0975)$ \\
\hline \multirow[t]{2}{*}{$\log (H-1 B s)$} & $2.205 * * *$ & $2.361 * * *$ & $2.042 * * *$ & $2.494 * * *$ & $1.724 * * *$ & $2.140 * * *$ & $2.521 * * *$ & $1.704 * * *$ \\
\hline & $(0.0967)$ & $(0.0618)$ & $(0.0658)$ & $(0.0724)$ & $(0.0428)$ & $(0.0537)$ & $(0.0654)$ & $(0.0357)$ \\
\hline Year & $\mathrm{N}$ & $\mathrm{Y}$ & $\mathrm{N}$ & $\mathrm{N}$ & $\mathrm{N}$ & $\mathrm{Y}$ & Y & $\mathrm{Y}$ \\
\hline Occupation & $\mathrm{N}$ & $\mathrm{N}$ & $\mathrm{Y}$ & $\mathrm{N}$ & $\mathrm{Y}$ & $\mathrm{Y}$ & $\mathrm{N}$ & $\mathrm{Y}$ \\
\hline $\begin{array}{l}\text { Commuting } \\
\text { Zone }\end{array}$ & $\mathrm{N}$ & $\mathrm{N}$ & $\mathrm{N}$ & $\mathrm{Y}$ & $\mathrm{Y}$ & $\mathrm{N}$ & $\mathrm{Y}$ & $\mathrm{Y}$ \\
\hline $\mathrm{N}$ & 56,237 & 56,237 & 56,237 & 56,155 & 56,237 & 56,237 & 56,155 & 56,155 \\
\hline
\end{tabular}

NOTE. $U R=$ Unemployment Rate. This is a negative binomial regression. This model is estimated at the year-labor market level, as defined by year, occupation, and commuting zone. The dependent variable is violations within a labor market and year. Exponentiated parameter estimates are reported, with robust standard errors in parentheses below each estimate. The coefficients are exponentiated and reflect the change in the rate of violations for a one standard deviation above average increase in the unemployment rate and a move from a competitive market to a monopsony.

$* \mathrm{P}<.10 ; * * \mathrm{P}<.05 ; * * * \mathrm{P}<.01$. Statistical significance on a two-tailed test of the null hypothesis that an individual predictor has no effect. 
Table A.6

INDUSTRY DEFINED LABOr MARKET LEVEL ANALYsis: THE EFFECT OF ECONOMIC CONDITIONS AND LABOR MARKET POWER ON VIOLATIONS

\begin{tabular}{|c|c|c|c|c|c|c|c|c|}
\hline & (1) & (2) & (3) & (4) & $(5)$ & $(6)$ & (7) & $(8)$ \\
\hline \multirow[t]{2}{*}{$U R$} & $0.510 * * *$ & 0.939 & 0.936 & $0.780 * * *$ & 0.932 & $1.432 * * *$ & 0.945 & 1.155 \\
\hline & $(0.0684)$ & $(0.108)$ & $(0.120)$ & $(0.0550)$ & $(0.0618)$ & $(0.190)$ & $(0.143)$ & $(0.142)$ \\
\hline \multirow[t]{2}{*}{$H H I$} & 1.860 & $0.153 * * *$ & $0.218 * * *$ & $0.248 * * *$ & 0.677 & $0.188 * * *$ & $0.286 * * *$ & $0.429 * * *$ \\
\hline & $(2.835)$ & $(0.0540)$ & $(0.107)$ & $(0.0785)$ & $(0.237)$ & $(0.0862)$ & $(0.0726)$ & $(0.123)$ \\
\hline \multirow[t]{2}{*}{$\log (H-1 B s)$} & $2.584 * * *$ & $2.741 * * *$ & $2.463 * * *$ & $2.955^{* * *}$ & $1.692 * * *$ & $2.779 * * *$ & $3.052 * * *$ & $2.034 * * *$ \\
\hline & $(0.307)$ & $(0.118)$ & $(0.186)$ & $(0.105)$ & $(0.0734)$ & $(0.128)$ & $(0.0833)$ & $(0.0825)$ \\
\hline Year & $\mathrm{N}$ & $\mathrm{Y}$ & $\mathrm{N}$ & $\mathrm{N}$ & $\mathrm{N}$ & $\mathrm{Y}$ & $\mathrm{Y}$ & $\mathrm{Y}$ \\
\hline Industry & $\mathrm{N}$ & $\mathrm{N}$ & $\mathrm{Y}$ & $\mathrm{N}$ & $\mathrm{Y}$ & $\mathrm{Y}$ & $\mathrm{N}$ & $\mathrm{Y}$ \\
\hline $\begin{array}{l}\text { Commuting } \\
\text { Zone }\end{array}$ & $\mathrm{N}$ & $\mathrm{N}$ & $\mathrm{N}$ & $\mathrm{Y}$ & $\mathrm{Y}$ & $\mathrm{N}$ & $\mathrm{Y}$ & $\mathrm{Y}$ \\
\hline $\mathrm{N}$ & 54,592 & 54,592 & 54,592 & 54,533 & 54,533 & 54,592 & 54,533 & 54,533 \\
\hline
\end{tabular}

NOTE. $U R=$ Unemployment Rate. This is a negative binomial regression. This model is estimated at the year-labor market level, as defined by year, industry, and commuting zone. The dependent variable is violations within a labor market and year. Exponentiated parameter estimates are reported, with robust standard errors in parentheses below each estimate. The coefficients are exponentiated and reflect the change in the rate of violations for a one standard deviation above average increase in the unemployment rate and a move from a competitive market to a monopsony.

$* \mathrm{P}<.10 ; * * \mathrm{P}<.05 ; * * * \mathrm{P}<.01$. Statistical significance on a two-tailed test of the null hypothesis that an individual predictor has no effect. 


\section{Appendix B: Wage and Hour Enforcement of Guest Worker Programs}

The Wage and Hour Division (WHD) of the U.S. Department of Labor is responsible for enforcing wage and hour regulations. Most of that enforcement is focused on the Fair Labor Standard Act (FLSA), and the part that focuses on the regulations of guest worker programs is somewhat different. A significant change followed a 2010 report to the WHD on "Strategic Enforcement." Prior to that report, the WHD's enforcement work was primarily reactive (initiated by worker complaints) (Weil 2010). ${ }^{36}$ The report recommended that the WHD behave more actively, launching proactive investigations focused on specific industry sectors. ${ }^{37}$ For $\mathrm{H}-$ 1Bs, for the duration of this study, enforcement has been driven entirely by worker complaints.

Wage theft against guest workers occurs when employers violate their pledge to pay guest workers and equivalent domestic workers a minimum wage that is the prevailing wage for a given occupation and location. Guest worker wage and hour enforcement is shaped by statute, regulations, inter-agency agreements, court decisions, and appropriations bills. For the H-1B visa, employers must file a Labor Condition Application, an enforceable promise to pay the $\mathrm{H}$ 1B worker the required prevailing wage in the location and occupation in which the worker(s) will be employed. This is a statutory requirement (see 20 CFR 655.731). The H-1B Visa Reform Act of 2004 specifies that the DOL "shall" provide employers at least 4 levels of prevailing wage "commensurate with experience, education, and the level of supervision." For each occupation and geography, there are therefore four effective wage floors set at the $17^{\text {th }}$ percentile (Level 1), the $34^{\text {th }}$ percentile (Level 2), the $50^{\text {th }}$ percentile (Level 3), and the $67^{\text {th }}$ percentile (Level 4 ). A final regulation toward the end of the Trump administration would have increased these wage floors to the $35^{\text {th }}, 62^{\text {nd }}, 78^{\text {th }}$, and $90^{\text {th }}$ percentiles, respectively. As of March 2021, the Biden administration has delayed implementation of these rules.

For H-1Bs, the WHD "enforces all elements of the LCA" under statutory authority granted in Subparts H and I of 20 CFR $\S 655$ and as outlined in the WHD Field Operations Handbook, Chapter 71 (2016). Under the H-1B Visa Reform Act of 2004, the WHD can only initiate H-1B related investigations with "reasonable cause," which the Field Operations Handbook further describes as a result of four factors:

\footnotetext{
${ }^{36}$ From 1998 to 2008, typically more than 75 percent of investigations arose from worker complaints.

${ }^{37}$ Since David Weil's elevation to the position of Wage and Hour administrator in 2014, and following the adoption of the strategic enforcement agenda articulated in the 2010 report, proactive investigations rose to over half of all investigations by 2017 (Weil 2018).
}

B.1 
- A complaint (may be anonymous) is received from an aggrieved party

- Credible information from a reliable source (a non-complainant) that the employer failed to meet LCA conditions

- The Secretary of Labor has found, on a case-by-case basis, that within the last five years an employer committed willful failure to meet a condition specified in the LCA. In such cases a random investigation may be conducted.

- The Secretary of Labor has reasonable cause to believe that the employer is not in compliance.

Each complaint "must be reviewed and/or screened," and the WHD is "required by the [Immigration and Naturalization Act] to issue a formal determination in every investigation and/or compliance action, and must assess back wages owed workers and other remedies as appropriate" (Field Operations Handbook, Chapter 71, p. 10). The WHD "lacks authority to close an investigation and/or compliance action administratively without issuance of a determination as to whether a violation occurred" (ibid, p. 9). Each complaint must have occurred within 12 months prior to the receipt of the complaint. Thus, for H-1B workers, the record is driven by complaints, which are documented. This means that the record is relatively comprehensive compared to mainstream enforcement efforts in which the WHD can administratively resolve complaints through a process of conciliation with the employer, without issuing determinations. 


\section{References}

Asbridge, J. B. 2016. Whose Job Is It Anyway: The Department of Labor's Authority to Make Labor Market Determinations under the H-2B Program. Drake L. Review 64, 273.

U.S. Department of Labor (2007). Wage and Hour Division. Field Assistance Bulletin. Enforcement Provisions Applicable to H-2B Workers. May 2, 2007. Accessed February 3, 2020. See https://www.dol.gov/sites/dolgov/files/WHD/legacy/files/FieldAssistanceBulletin2007_1.pdf

U.S. Department of Labor (2015). Wage and Hour Division. Fact Sheet \#78A: Corresponding Employment Under the H-2B Program. April 2015. Accessed February 3, 2020. See https://www.dol.gov/sites/dolgov/files/WHD/legacy/files/whdfs78a.pdf

U.S. Department of Labor (2016). Wage and Hour Division. Field Operations Handbook Chapter 46. Revised August 10, 2016. Accessed February 3, 2020. See https://www.dol.gov/agencies/whd/field-operations-handbook/Chapter-46

U.S. Department of Labor (2016). Wage and Hour Division. Field Operations Handbook Chapter 71. Enforcement of H-1B Labor Condition Application. Revised September 27, 2016. Accessed February 3, 2020. See https://www.aila.org/infonet/whd-field-operationshandbook-enforcement-of-h-1b

Weil, David. 2010. Improving workplace conditions through strategic enforcement. Report to the Wage and Hour Division, U.S. Department of Labor, May 2010.

Weil, David. 2018. Creating a strategic enforcement approach to address wage theft: One academic's journey in organizational change. Journal of Industrial Relations 60(3): 437-46. 